\title{
Synthesis of structurally diverse and defined bivalent mannosides on saccharide scaffolding
}

Manuela Tosin, Sebastien Gouin and Paul V. Murphy*

Centre for Synthesis and Chemical Biology, Chemistry Department, Conway Institute of Biomolecular and Biomedical Research,

University College Dublin, Belfield, Dublin 4, Ireland.

paul.v.murphy@ucd.ie

Index

P2-3 Analytical data for Compounds 2-5

P4-11 ${ }^{1} \mathrm{H}$ and ${ }^{13} \mathrm{C}-\mathrm{NMR}$ spectra for 2-5

P11-43 ${ }^{1} \mathrm{H}$ and ${ }^{13} \mathrm{C}-\mathrm{NMR}$ spectra for novel intermediates in Scheme 1-4

P44-53 Computational data and graphs 


\section{Analytical data for compounds 2-5}

\section{Compound 2}

${ }^{1}$ H-NMR $\left(500 \mathrm{MHz}, \mathrm{D}_{2} \mathrm{O}\right): \delta 8.02(\mathrm{~s}, 4 \mathrm{H}$, aromatic $\mathrm{H}), 5.40$ (apparent s, 2H, mannose H1), 5.35 (d, $2 \mathrm{H}, J_{1,2} 9.3$, glucuronic acid $\left.\mathrm{H}-1\right), 5.30$ (t, 2H, $J_{3,4} 10.0, J_{4,5} 10.0$, mannose $\mathrm{H}-$ 4), 4.18 (apparent s, 2H, mannose $\mathrm{H}-2), 4.08(\mathrm{~m}, 2 \mathrm{H}$, mannose $\mathrm{H}-5), 3.99\left(\mathrm{~d}, 2 \mathrm{H}, J_{4,5}\right.$ 10.0, H-5), 3.97 (m, $2 \mathrm{H}$, mannose $\mathrm{H}-3$ ', partially overlapping with $\mathrm{H}-5), 3.95-3.78(\mathrm{~m}, 8$ $\mathrm{H}$, mannose $\mathrm{H}-6 \mathrm{a}, \mathrm{H}-6 \mathrm{~b}$, and glucuronic acid $\mathrm{H}-4$ and $\mathrm{H}-3), 3.76\left(\mathrm{t}, 2 \mathrm{H}, J_{2,3} 9.0\right.$, glucuronic acid $\mathrm{H}-2)$.

${ }^{13}$ C-NMR $\left(\mathrm{D}_{2} \mathrm{O}\right): \delta 173.6(2 \mathrm{~s}, \mathrm{CONH}$ and $\mathrm{COOH}), 139.4(\mathrm{~s}$, aromatic $\mathrm{C}), 130.7(\mathrm{~d}$, aromatic $\mathrm{CH}$ ), 103.7 (d, mannose $\mathrm{C}-1$ ), 85.1 (d, glucuronic acid $\mathrm{C}-1$ ), 82.6, 75.6, 75.2, $73.3,73.2,73.1(2 \mathrm{~s}), 69.4($ each d), $63.6(\mathrm{t})$.

ES-HRMS: Found 839.2230, required 839.2206 [M-H].

\section{Compound 3}

${ }^{1}$ H-NMR $\left(\mathrm{D}_{2} \mathrm{O}, 300 \mathrm{MH}_{\mathrm{Z}}\right) \delta(\mathrm{ppm}): 7.96\left(4 \mathrm{H}, \mathrm{s}\right.$, aromatic H), $5.43\left(2 \mathrm{H}, \mathrm{d}, \mathrm{J}_{1,2}=8.4 \mathrm{~Hz}\right.$, glucose $\mathrm{H}-1), 4.90$ (2H, s, mannose $\mathrm{H}-1), 3.98-3.55$ (24H, m).

${ }^{13} \mathbf{C}-\mathrm{NMR}\left(\mathrm{CDCl}_{3}, 75 \mathrm{MH}_{\mathrm{Z}}\right) \delta(\mathrm{ppm}): 173.7(\mathrm{NHCO}), 139.4$ (s, aromatic C), $130.8(\mathrm{~d}$, aromatic $\mathrm{CH}) 102.5$ (d, mannose $\mathrm{C}-1), 83.0$ (d, glucose $\mathrm{C}-1), 79.6,78.8,75.5,74.5,73.4$, 72.7, 72.1, 69.4 (each d), 68.5 and 63.7 (each t).

ES-HRMS: $\left[\mathrm{M}+\mathrm{Na}^{+}\right]$calcd. 835.2596, found 835.2571.

\section{Compound 4}

${ }^{1}$ H-NMR $\left(\mathrm{D}_{2} \mathrm{O}, 300 \mathrm{MH}_{\mathrm{Z}}\right) \delta(\mathrm{ppm}): 7.96(4 \mathrm{H}, \mathrm{s}$, aromatic $\mathrm{H}), 5.36(2 \mathrm{H}, \mathrm{s}$, mannose $\mathrm{H}-1)$, $5.22\left(2 \mathrm{H}, \mathrm{d}, \mathrm{J}_{1,2}=9.0 \mathrm{~Hz}\right.$, glucose $\left.\mathrm{H}_{1}\right), 4.10(2 \mathrm{H}, \mathrm{s}), 3.95-3.59(22 \mathrm{H}, \mathrm{m}), 3.60\left(2 \mathrm{H}, \mathrm{t}, \mathrm{J}_{1,2}=\right.$ $9.0 \mathrm{~Hz}, \mathrm{~J}_{2,3}=9.0 \mathrm{~Hz}$, glucose $\mathrm{H}_{2}$ ).

${ }^{13}$ C-NMR $\left(\mathrm{D}_{2} \mathrm{O}, 75 \mathrm{MH}_{\mathrm{Z}}\right) \delta(\mathrm{ppm}): 173.7(\mathrm{NHCO}), 139.4$ (s, aromatic C), $130.8(\mathrm{~d}$, aromatic $\mathrm{CH}) 104.2$ (d, C-1, mannose), 82.6 (d, C-1, glucose), 79.9, 79.3, 78.5, 76.6, 74.7, 73.2, 73.1, 69.4 (each d), 63.7, 63.4 (each t).

ES-HRMS: (M-H) ${ }^{-}$calcd. 811.2620, found 811.2656.

\section{Compound 5}

${ }^{1}$ H-NMR (500 MHz, D $\left.2 \mathrm{O}\right): \delta 7.60\left(\mathrm{~s}, 4 \mathrm{H}\right.$, aromatic H), 5.35 (d, 2H, $J_{1,2} 1.4$, mannose H1), 4.98 (d, 2H, $J_{1,2} 9.0$, glucuronic acid $\left.\mathrm{H}-1\right), 4.24$ (d, $2 \mathrm{H}, J_{4,5} 9.5$, glucuronic acid $\mathrm{H}-5$ ), 4.14 (m, 2H, mannose H-2), 4.06 (m, 2H, mannose H-6), 3.96-3.86 (m, 10H, mannose H- 
6a, H-4, H-5, H-3, glucose H-3), 3.81 (t, 2H, $J_{3,4} 10.0$, glucuronic acid $\left.\mathrm{H}-4\right), 3.54$ (t, $2 \mathrm{H}$, $J_{2,3} 9.0$, glucuronic acid $\mathrm{H}-2$ ).

${ }^{13}$ C-NMR $\left(\mathrm{D}_{2} \mathrm{O}\right): \delta 171.2(\mathrm{~s}, \mathrm{CONH}), 136.4$ (s, aromatic $\left.\mathrm{C}\right), 125.9(\mathrm{~d}$, aromatic $\mathrm{CH})$, 103.8 (d, mannose C-1), 93.1 (d, glucuronic acid C-1), 84.1, 79.9, 75.7, 74.4, 74.0, 73.2, 73.1, 69.3 (each d), 63.5 (t, mannose C-6)

ES-HRMS: Found 835.2626, required $835.2594[\mathrm{M}+\mathrm{H}]^{+}$ 


\section{${ }^{1}$ H-NMR Spectrum of 2}

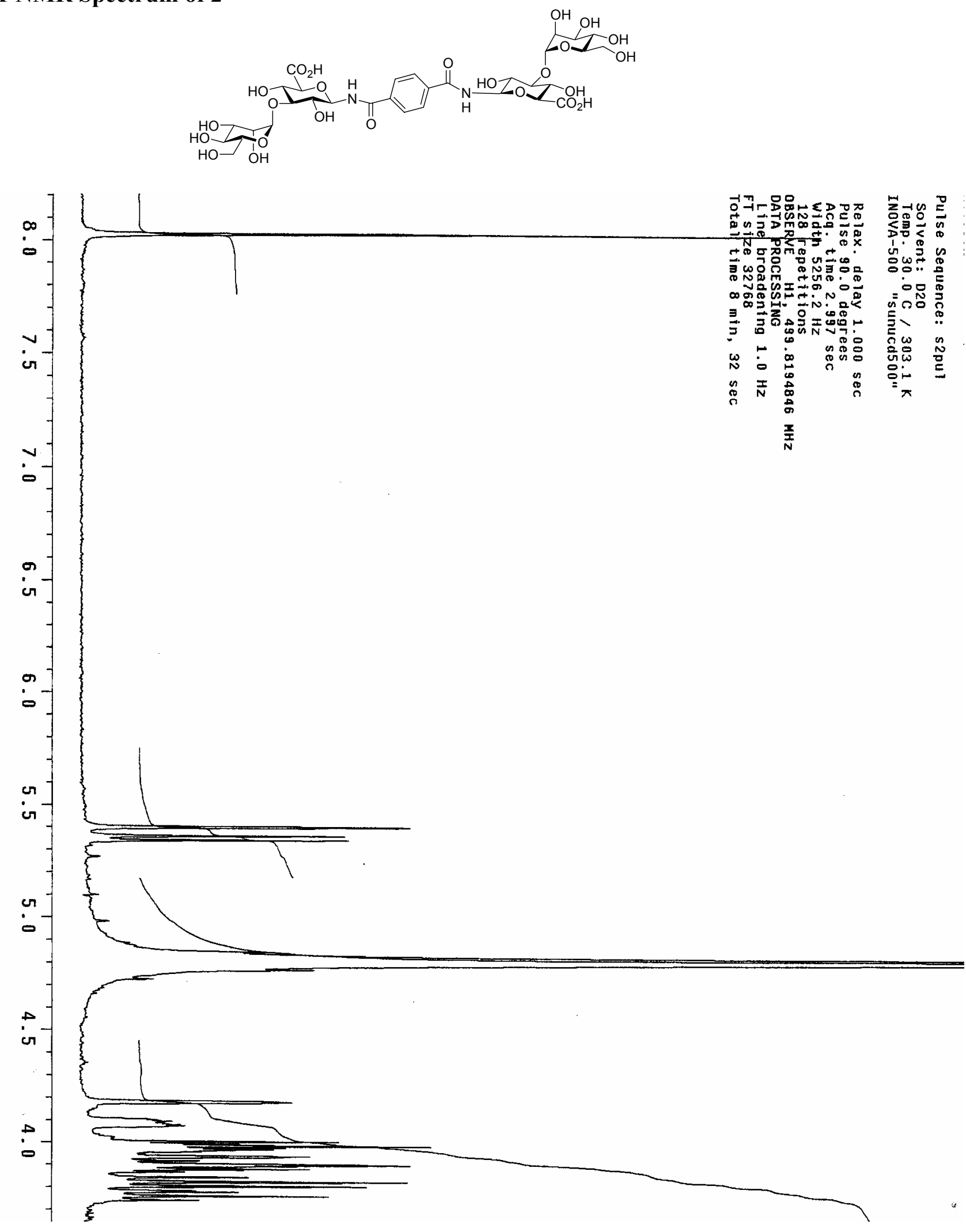




\section{${ }^{13}$ C-NMR of 2}

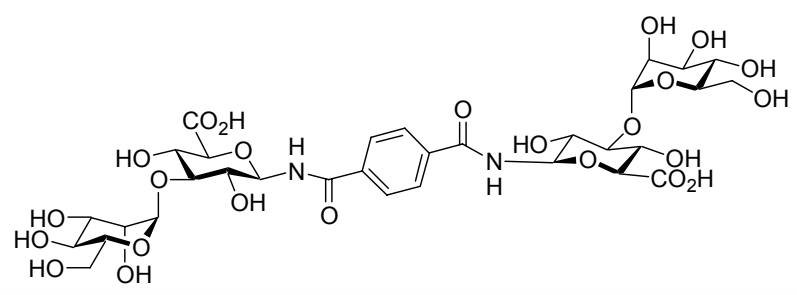
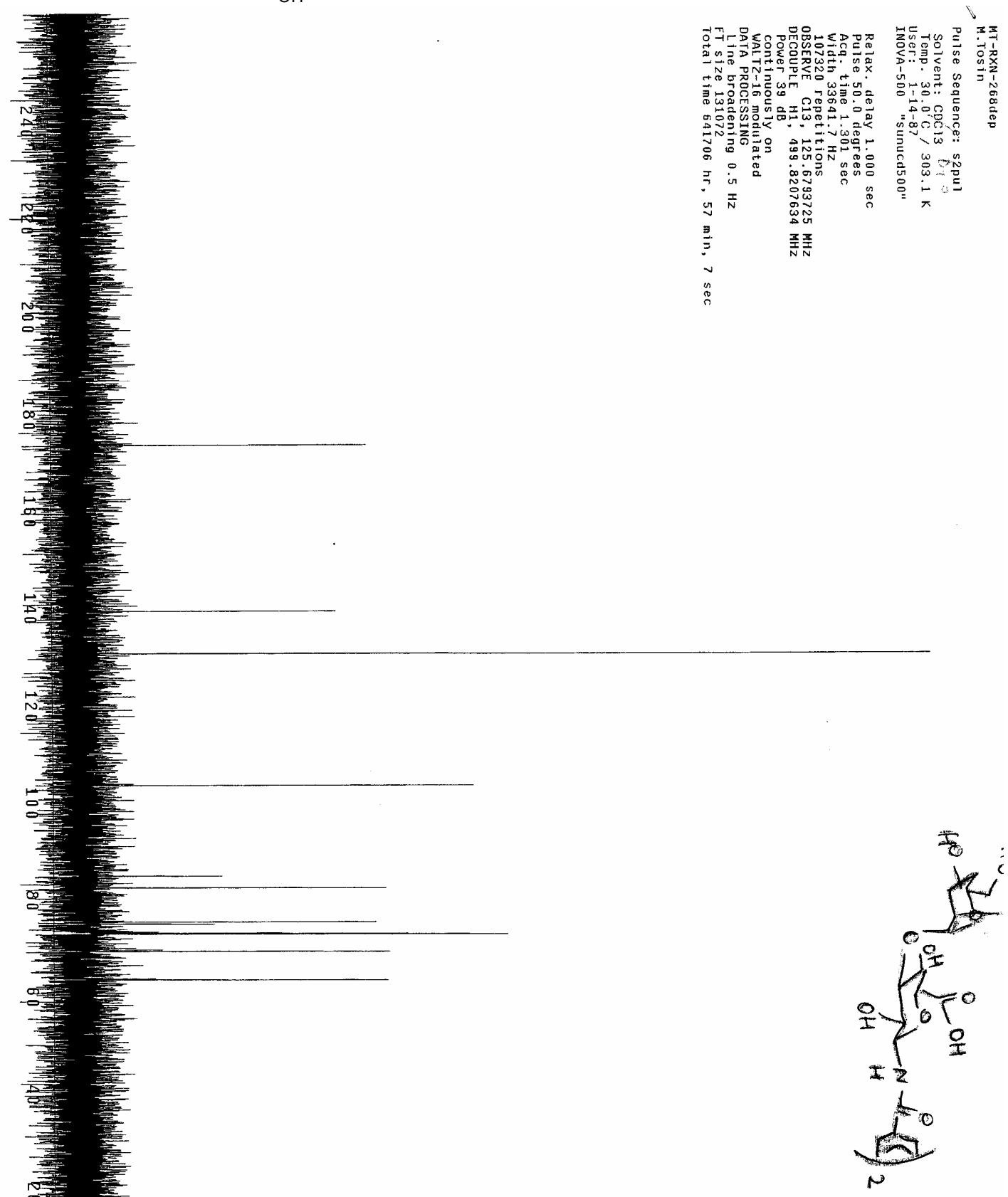


\section{${ }^{1}$ H-NMR Spectrum of 3}

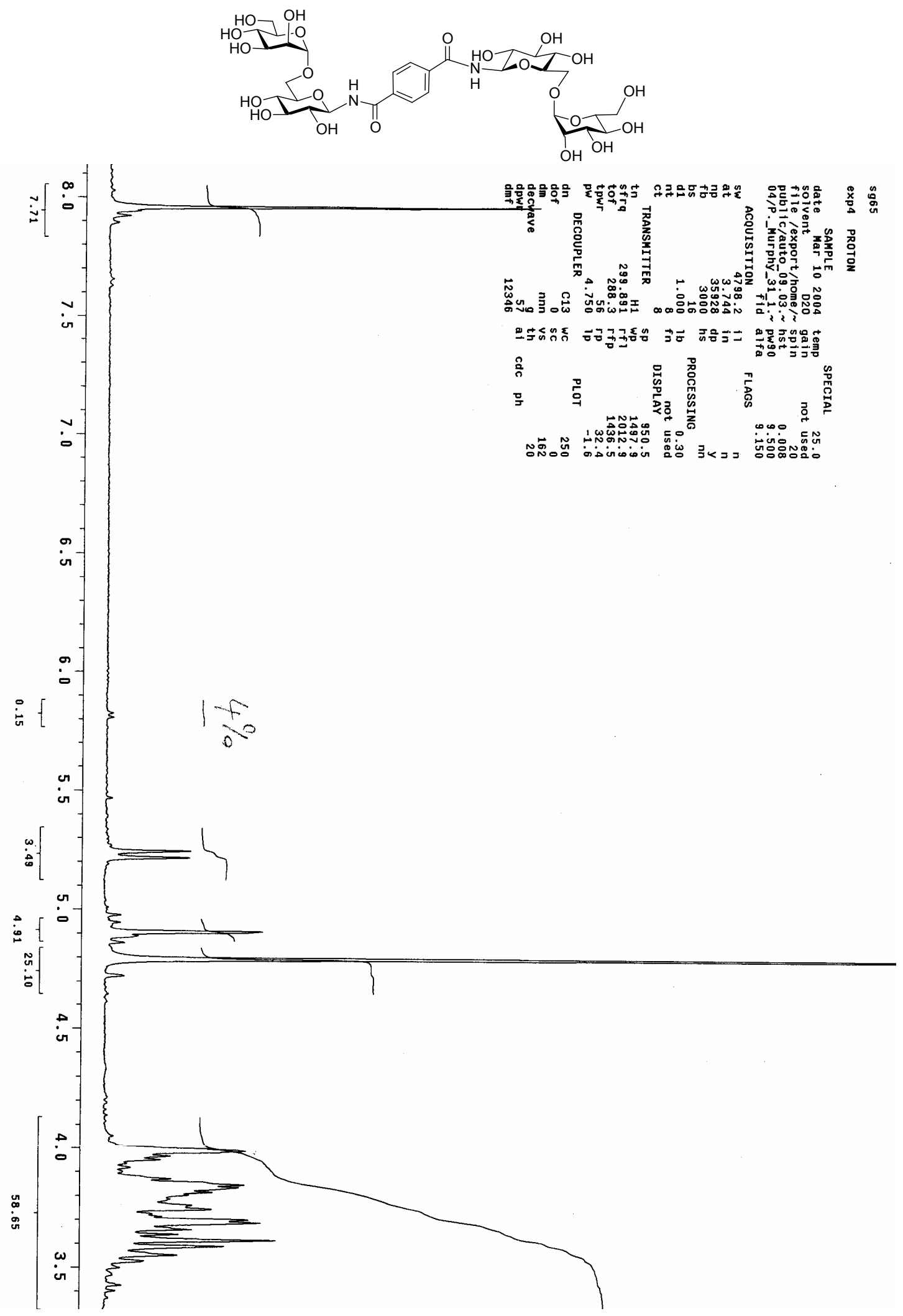




\section{${ }^{13}$ C-NMR Spectrum of 3}
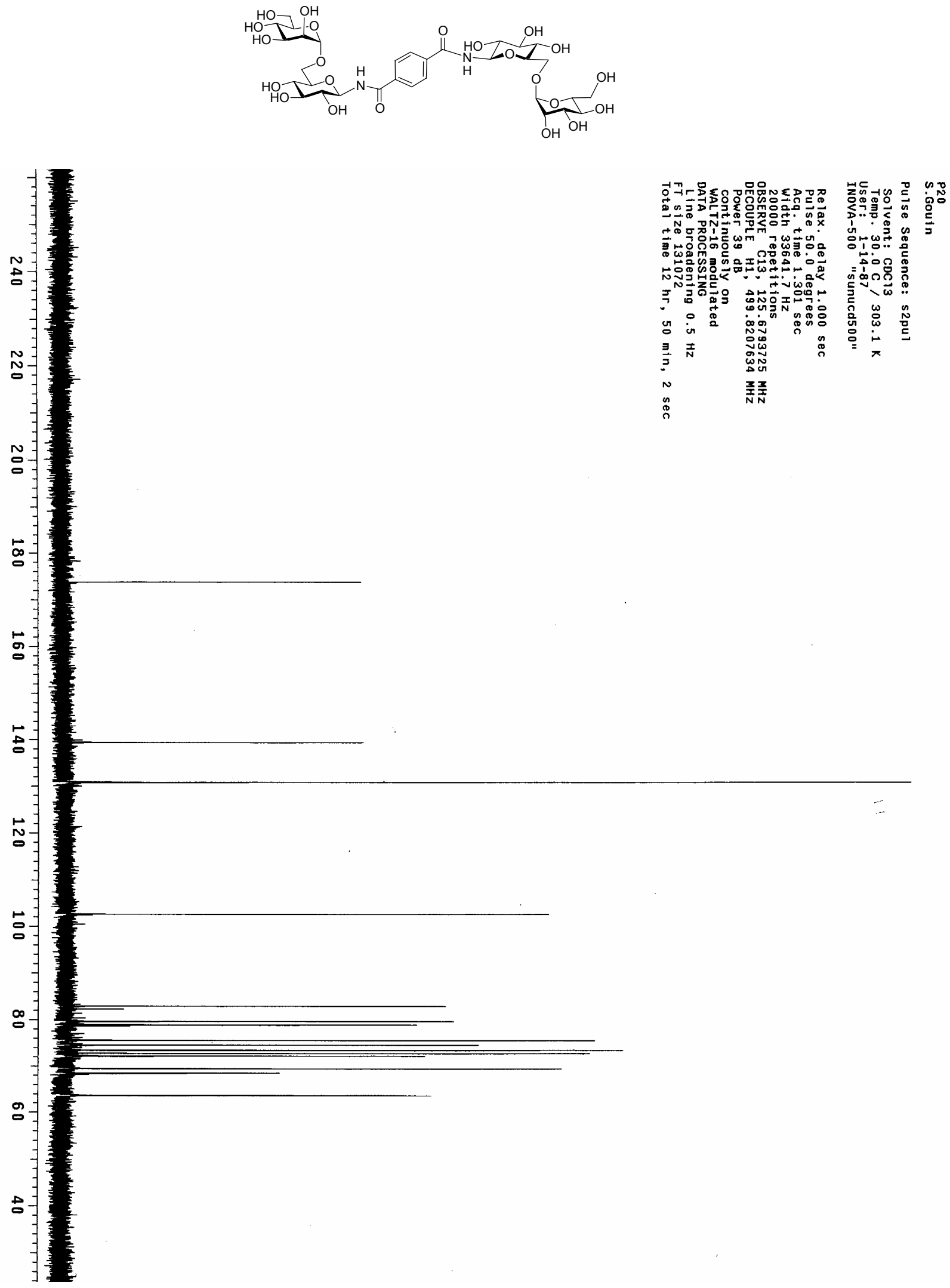


\section{${ }^{1}$ H-NMR Spectrum 4}

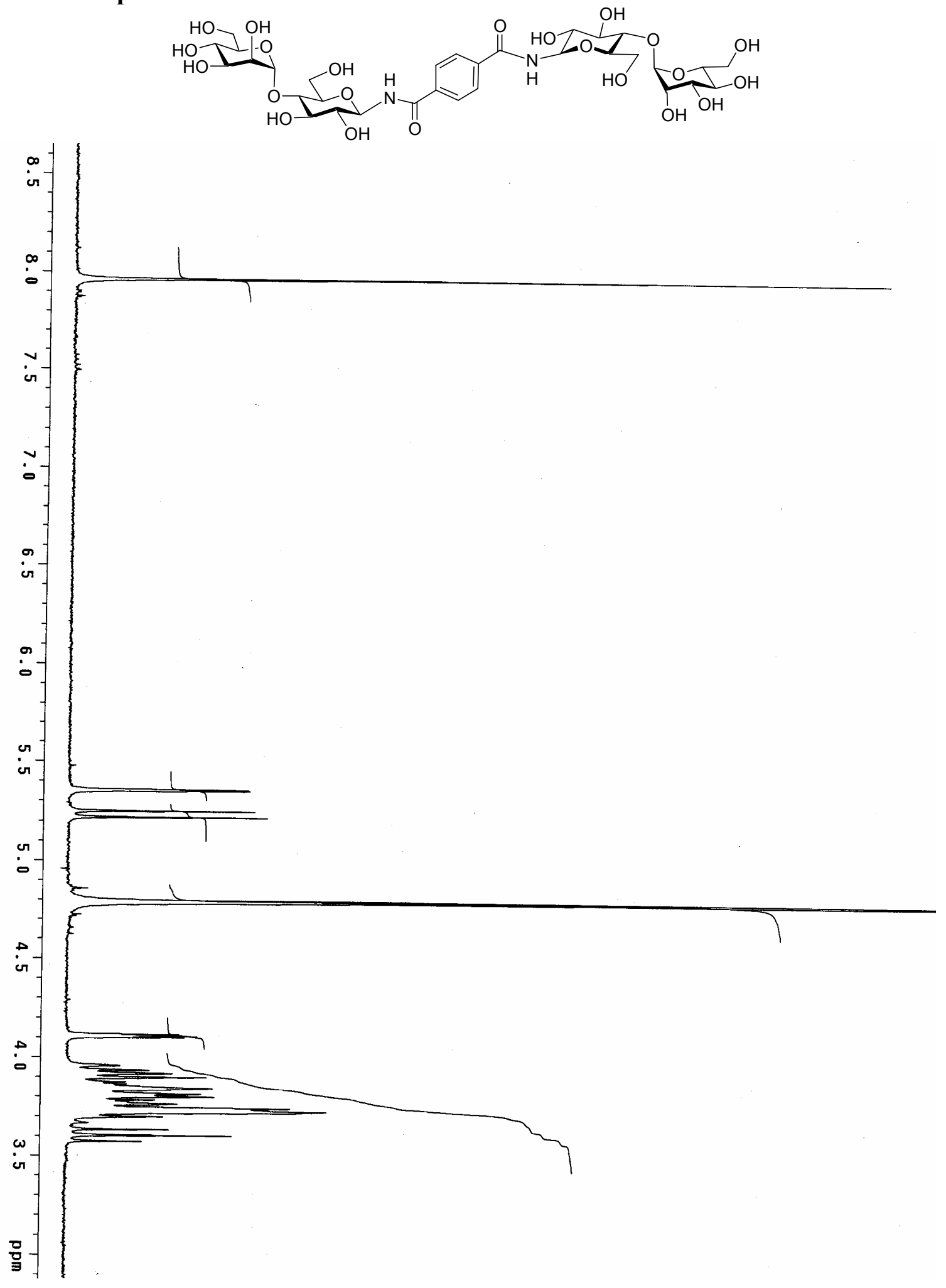




\section{${ }^{13}$ C-NMR Spectrum of 4}
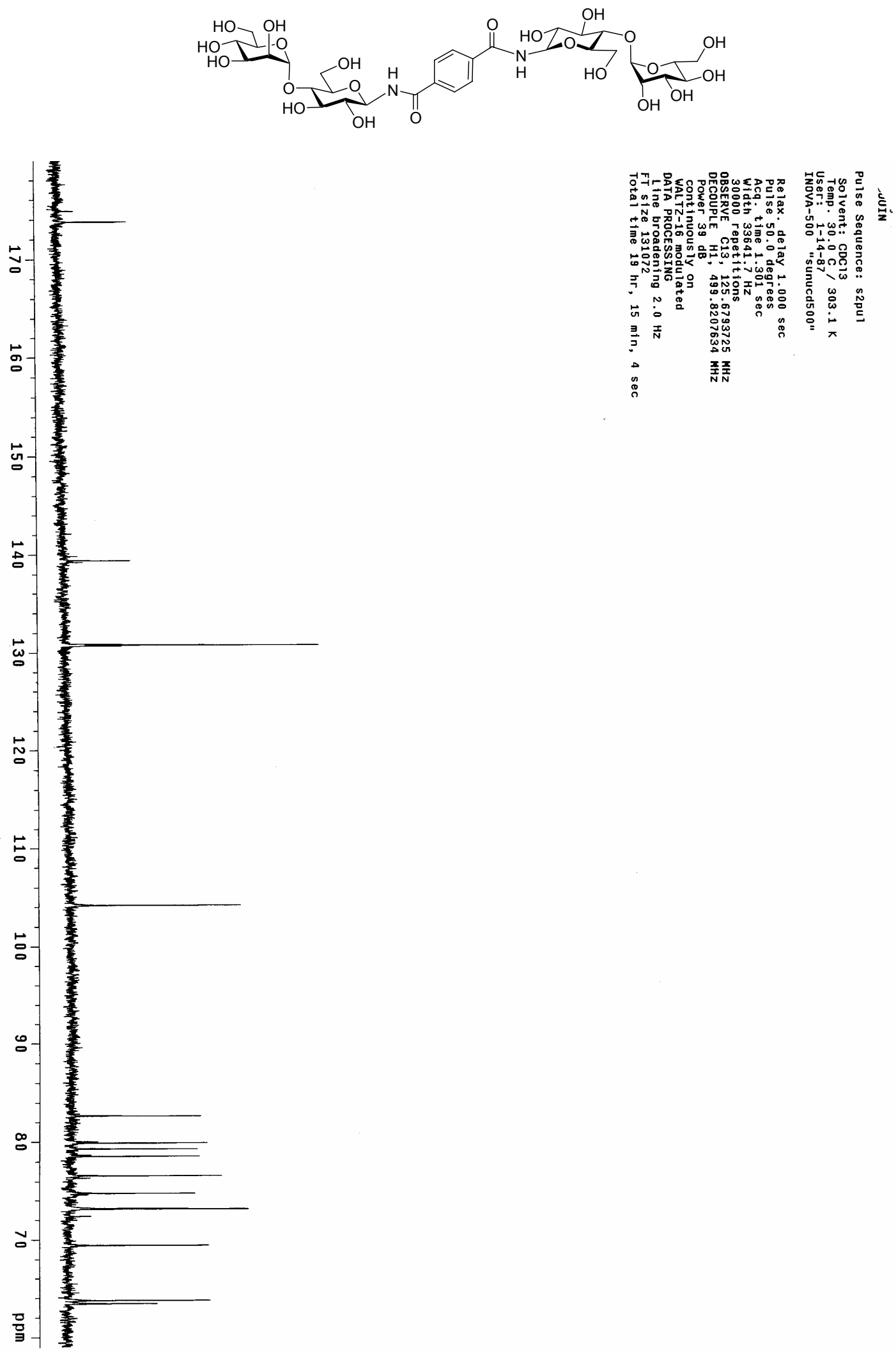


\section{${ }^{1}$ H-NMR of 5}

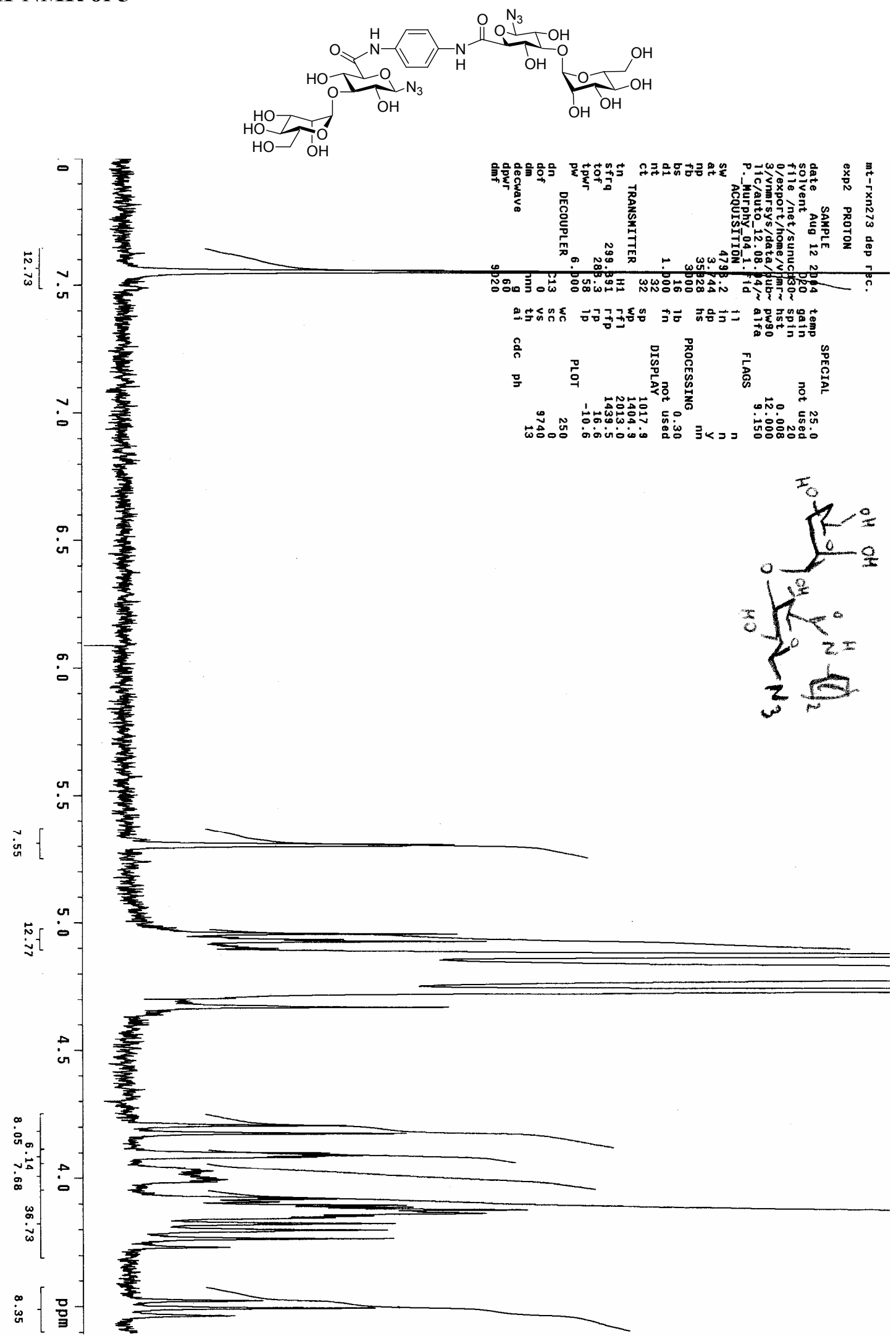




\section{${ }^{13} \mathrm{C}-\mathrm{NMR}$ of 5}
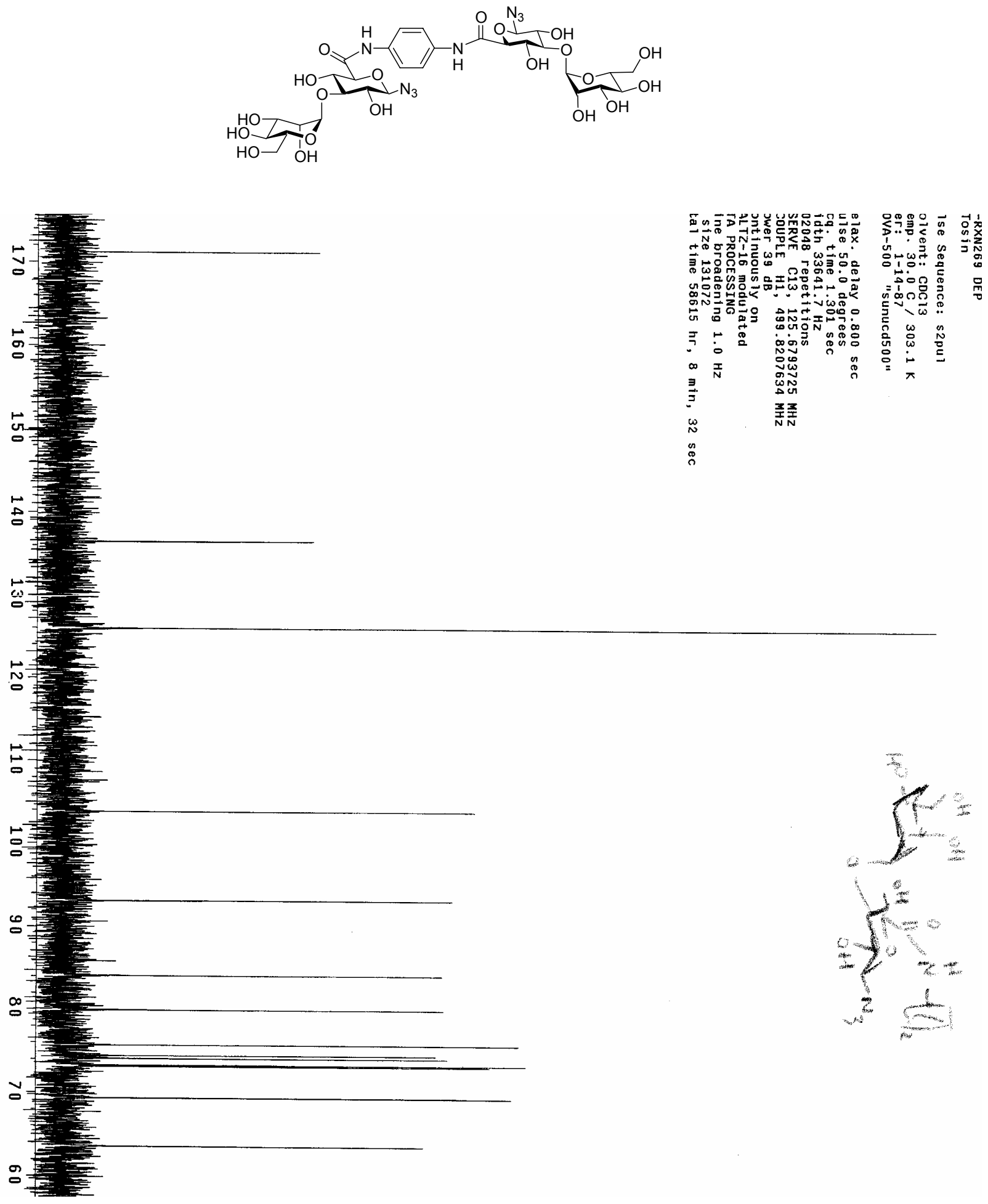


\section{NMR Spectra of Intermediates}

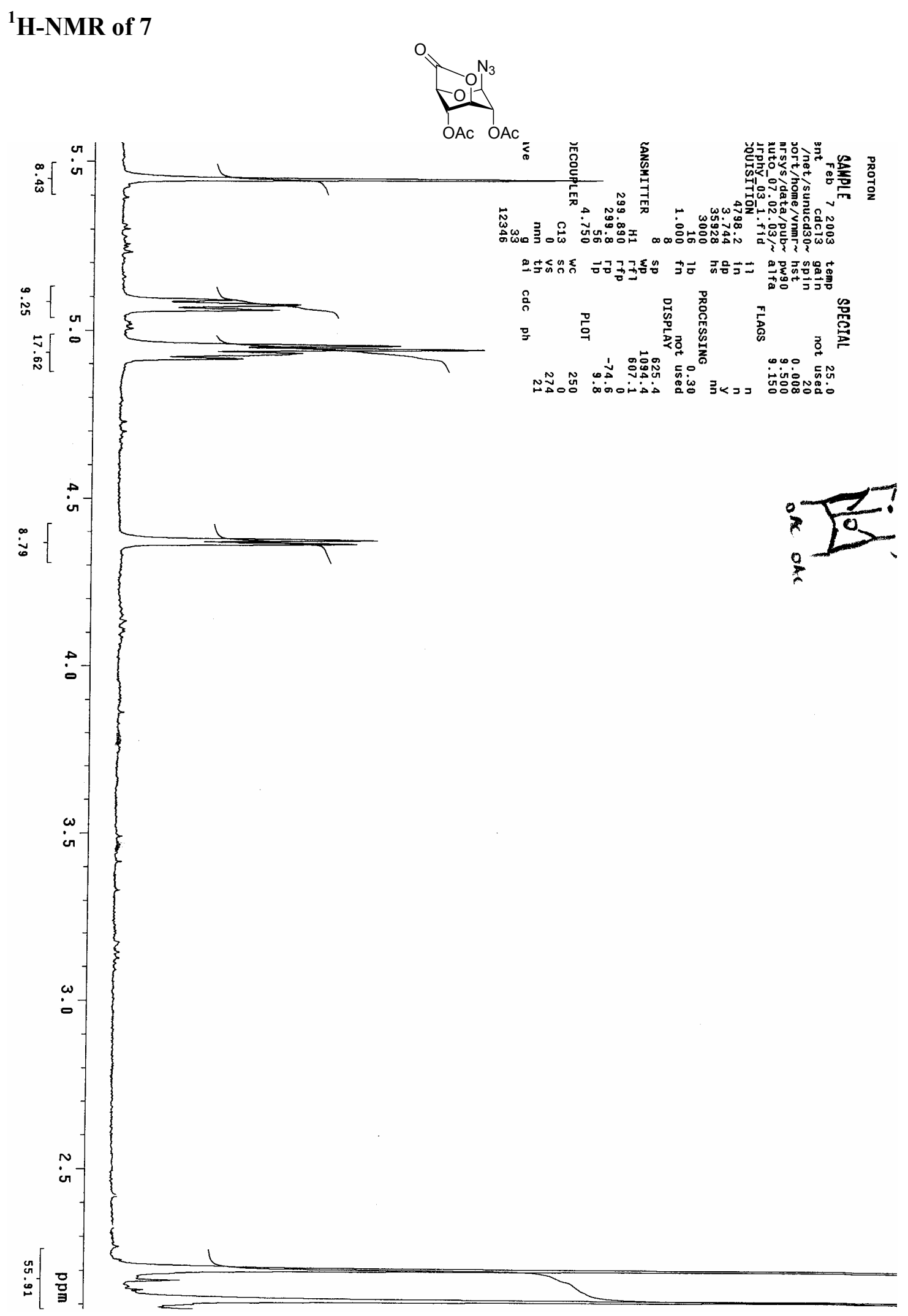




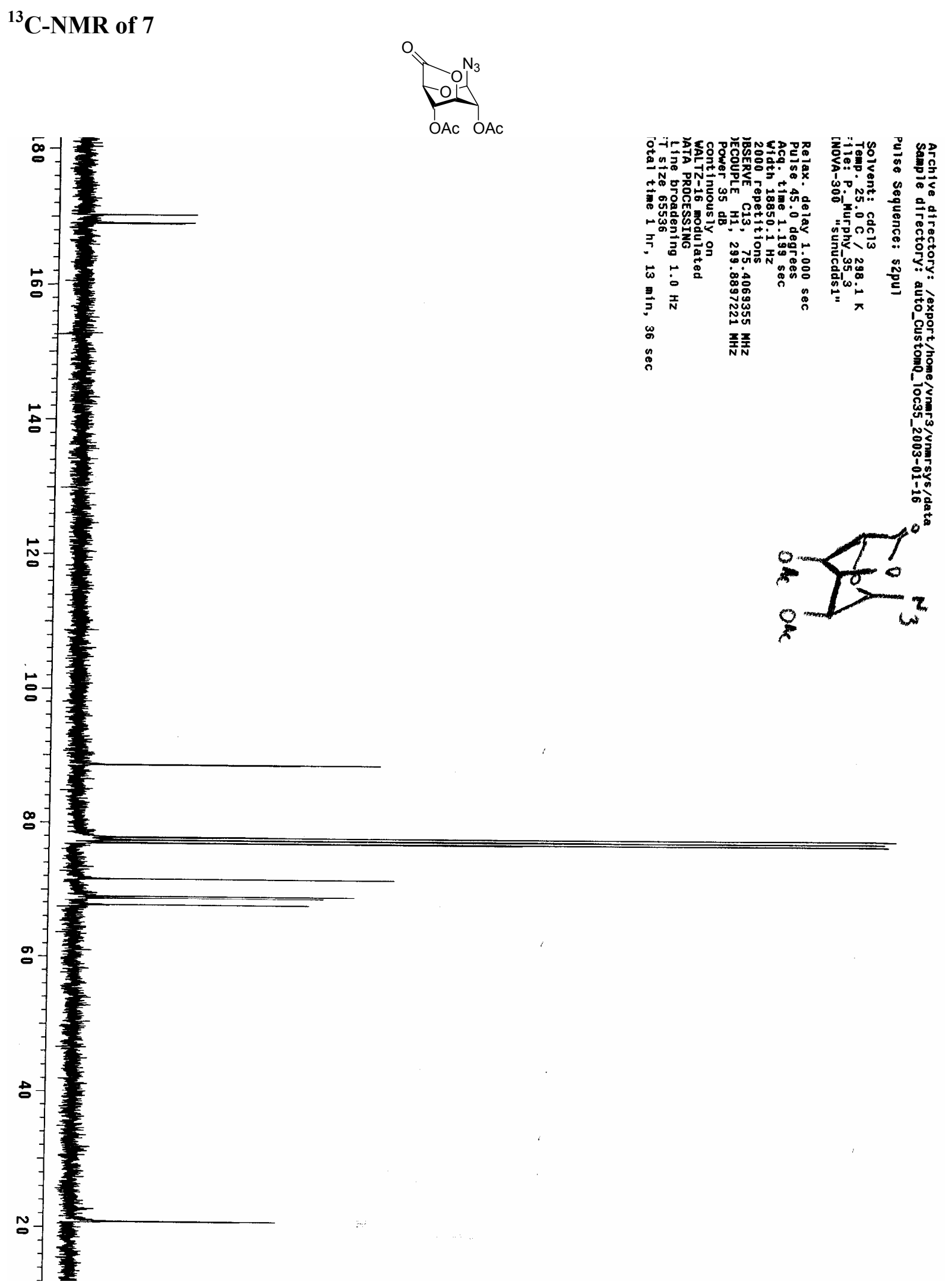




\section{${ }^{1}$ H-NMR of 8}

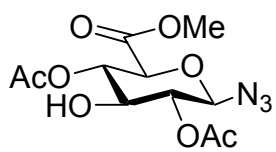

के

$$
\text { : }
$$

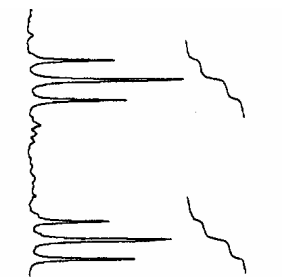

कू

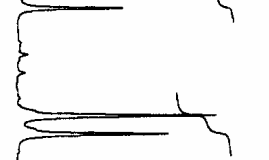

in
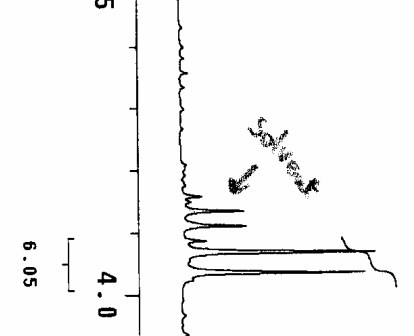

$$
\text { : }
$$
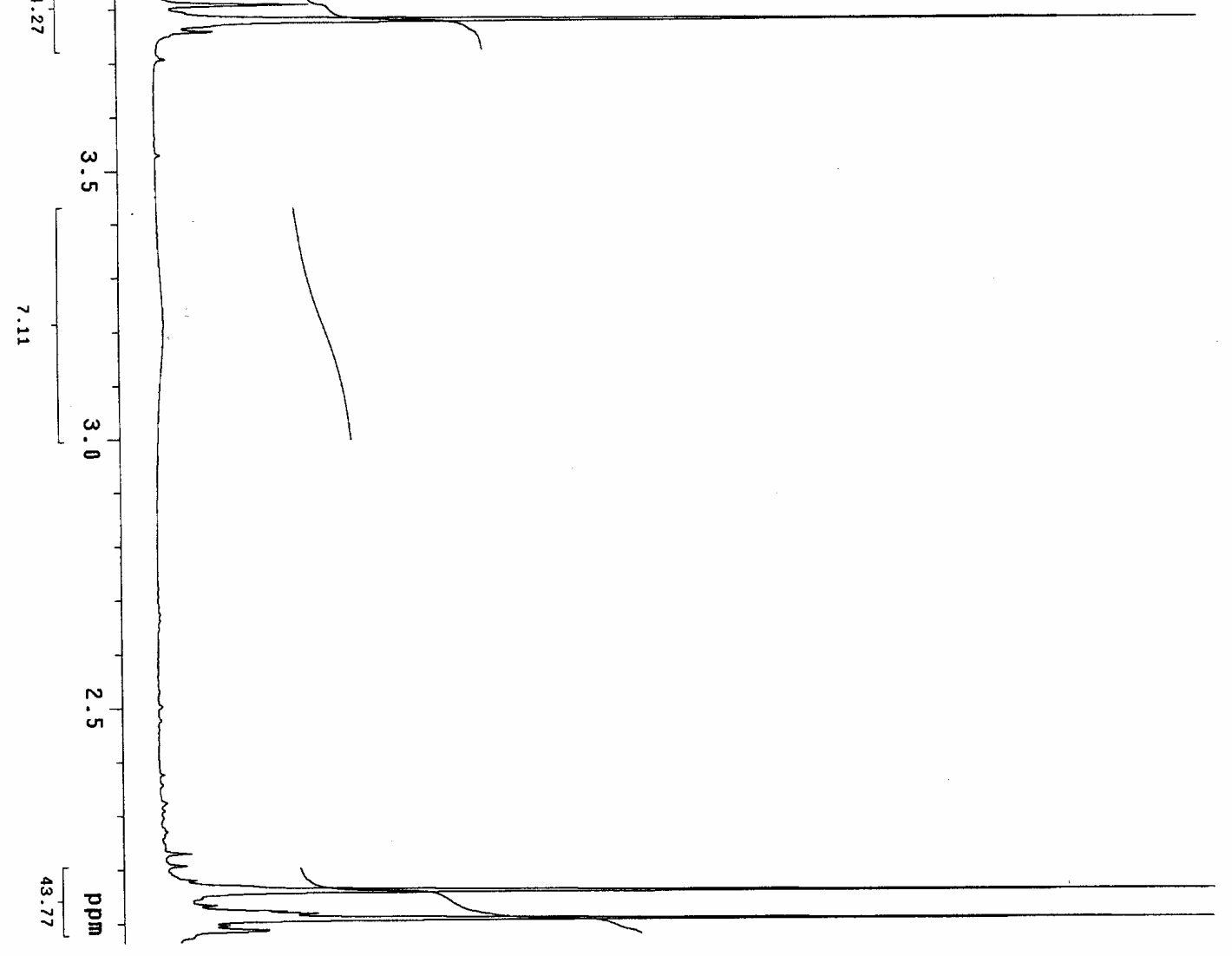


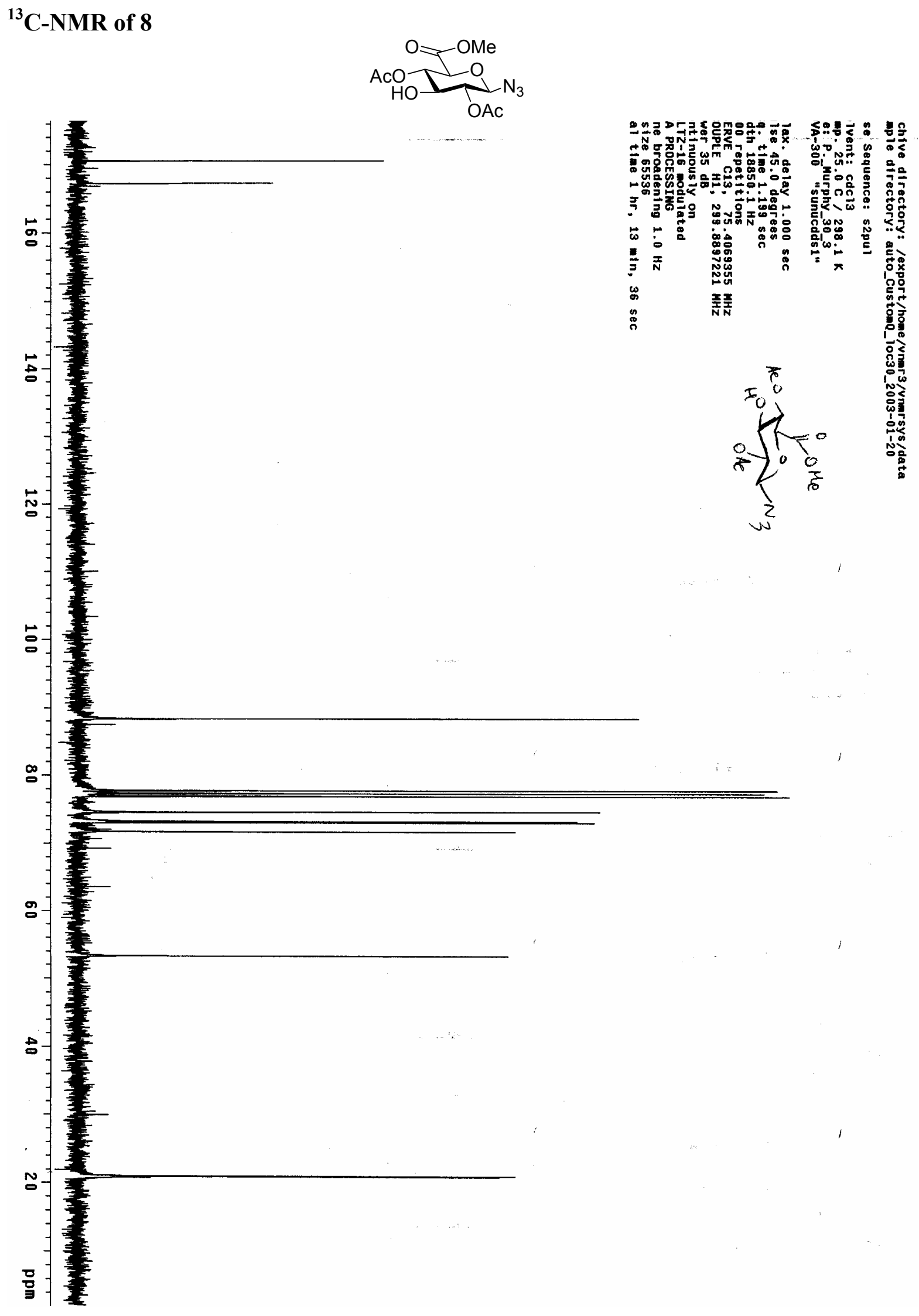




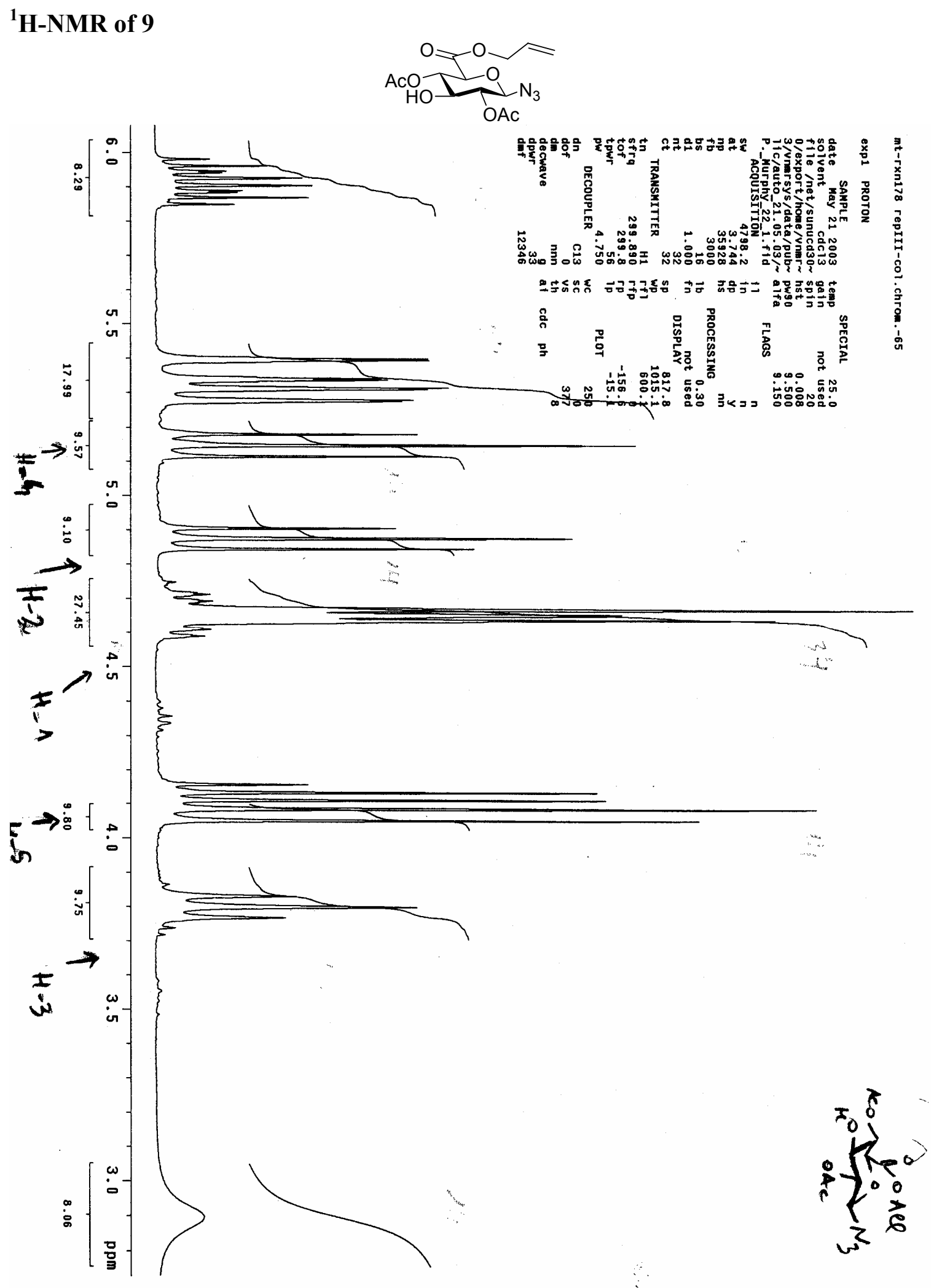




\section{${ }^{13}$ C-NMR of 9}
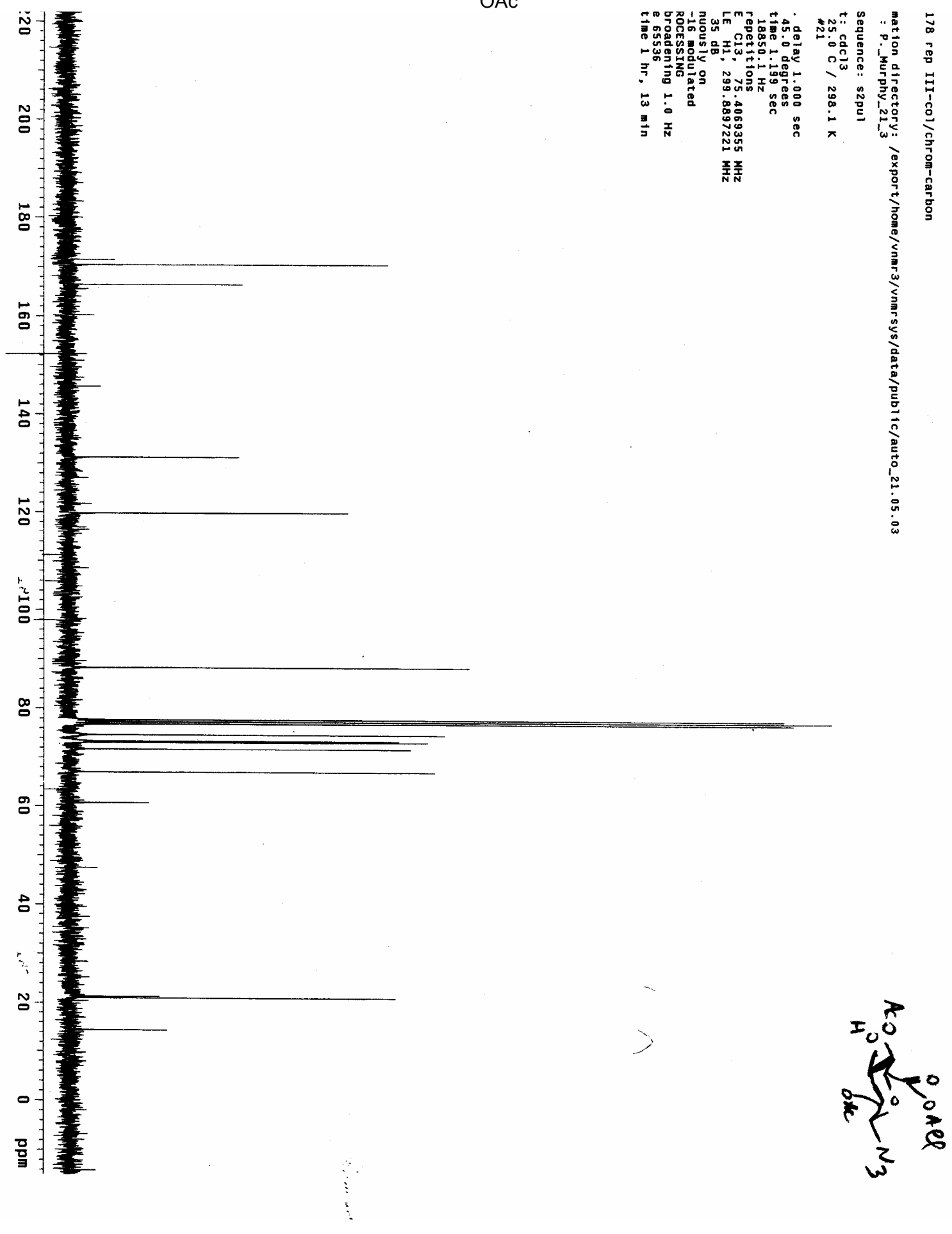


\section{${ }^{1}$ H-NMR of 11}

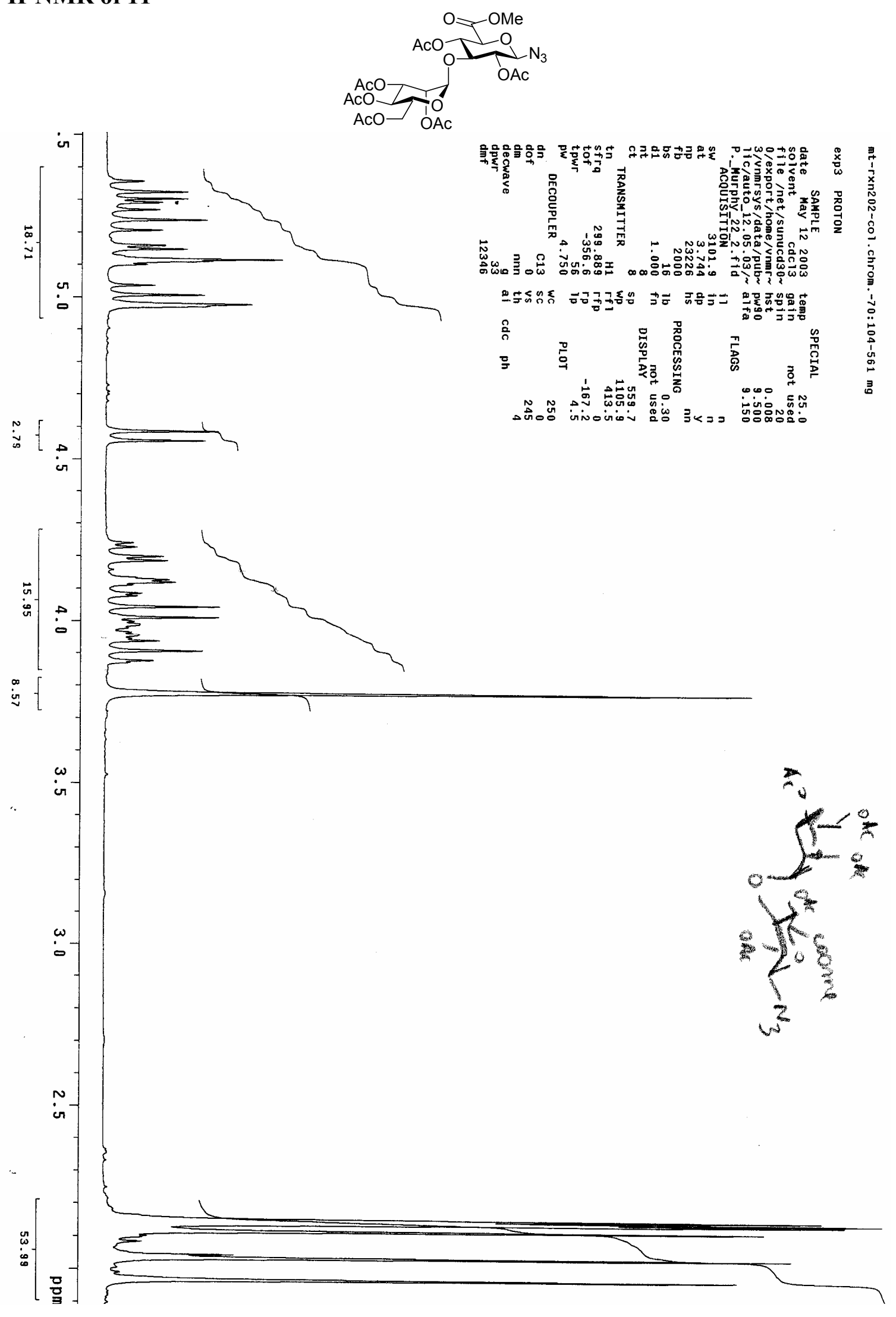


${ }^{13}$ C-NMR of 11
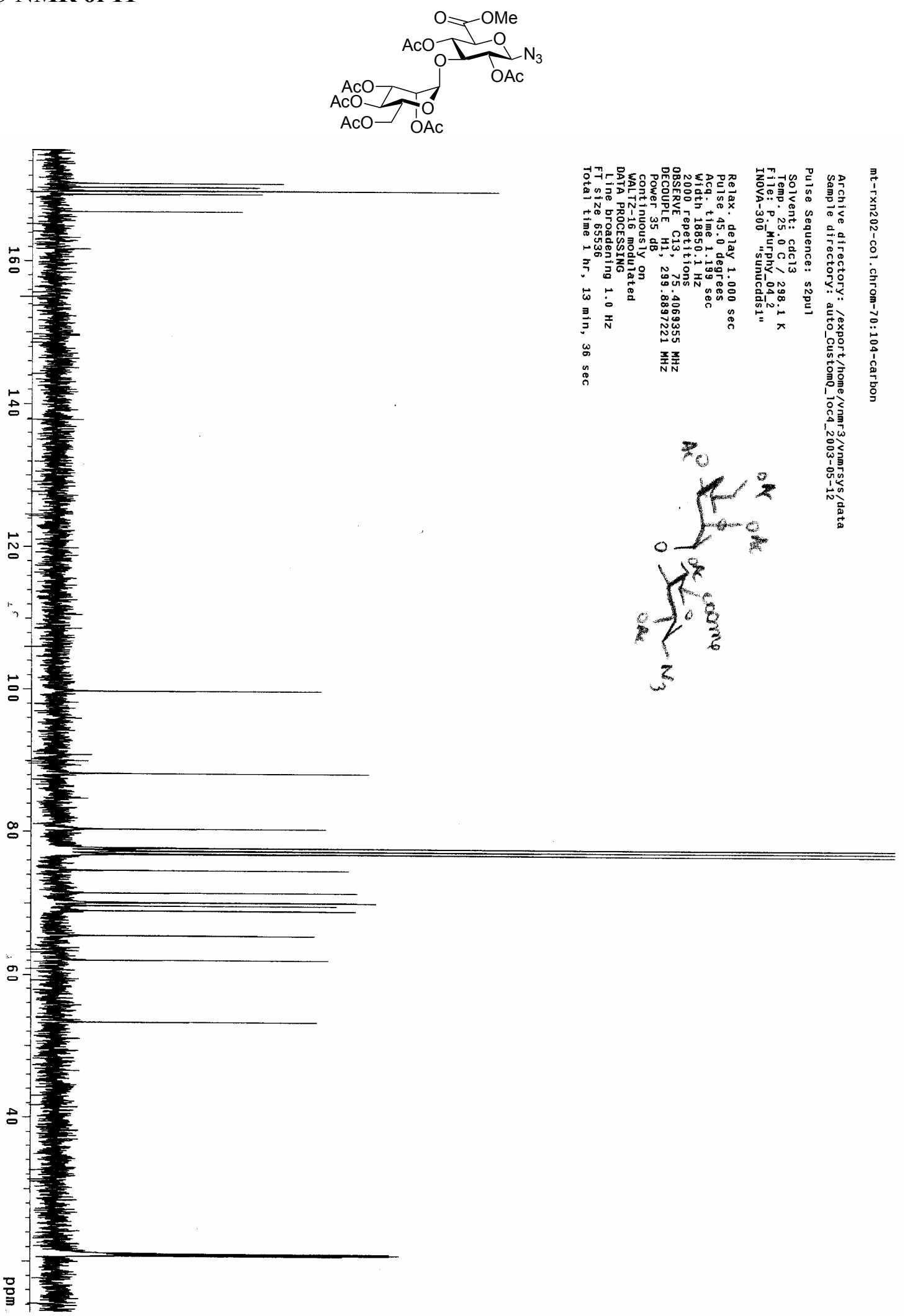


\section{${ }^{1}$ H-NMR of 12}

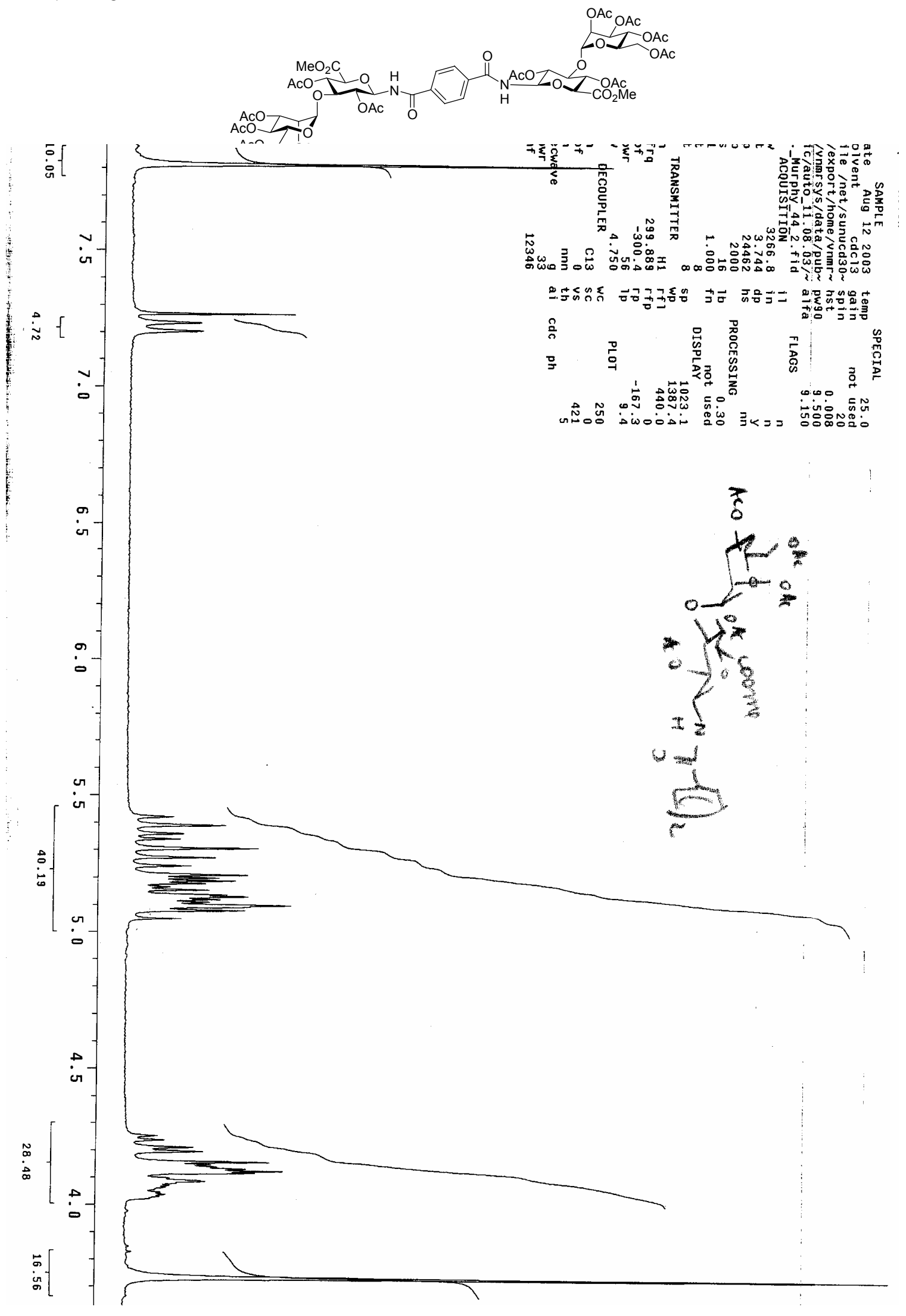




\section{${ }^{13}$ C-NMR of 12}

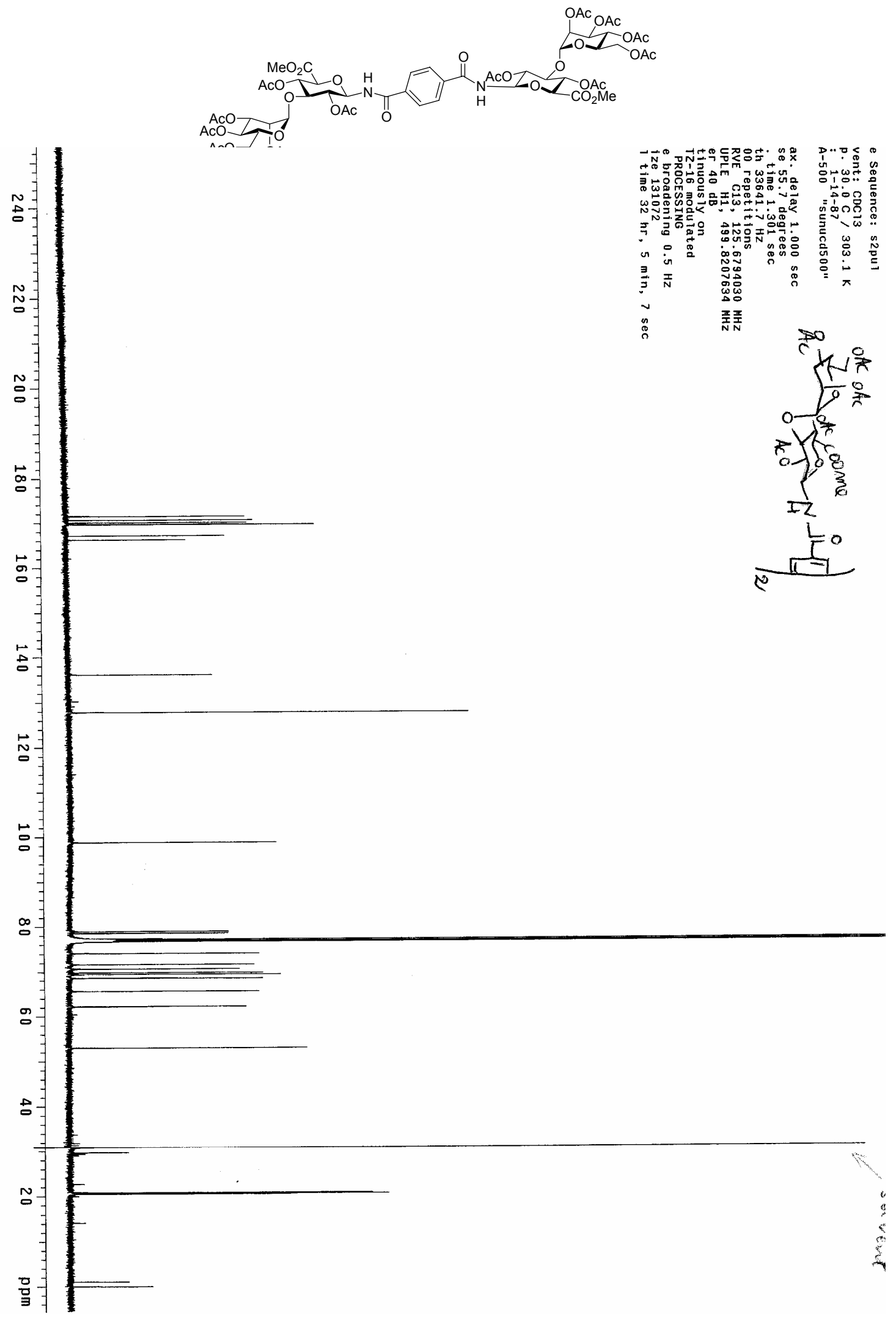




\section{${ }^{1}$ H-NMR of 14}

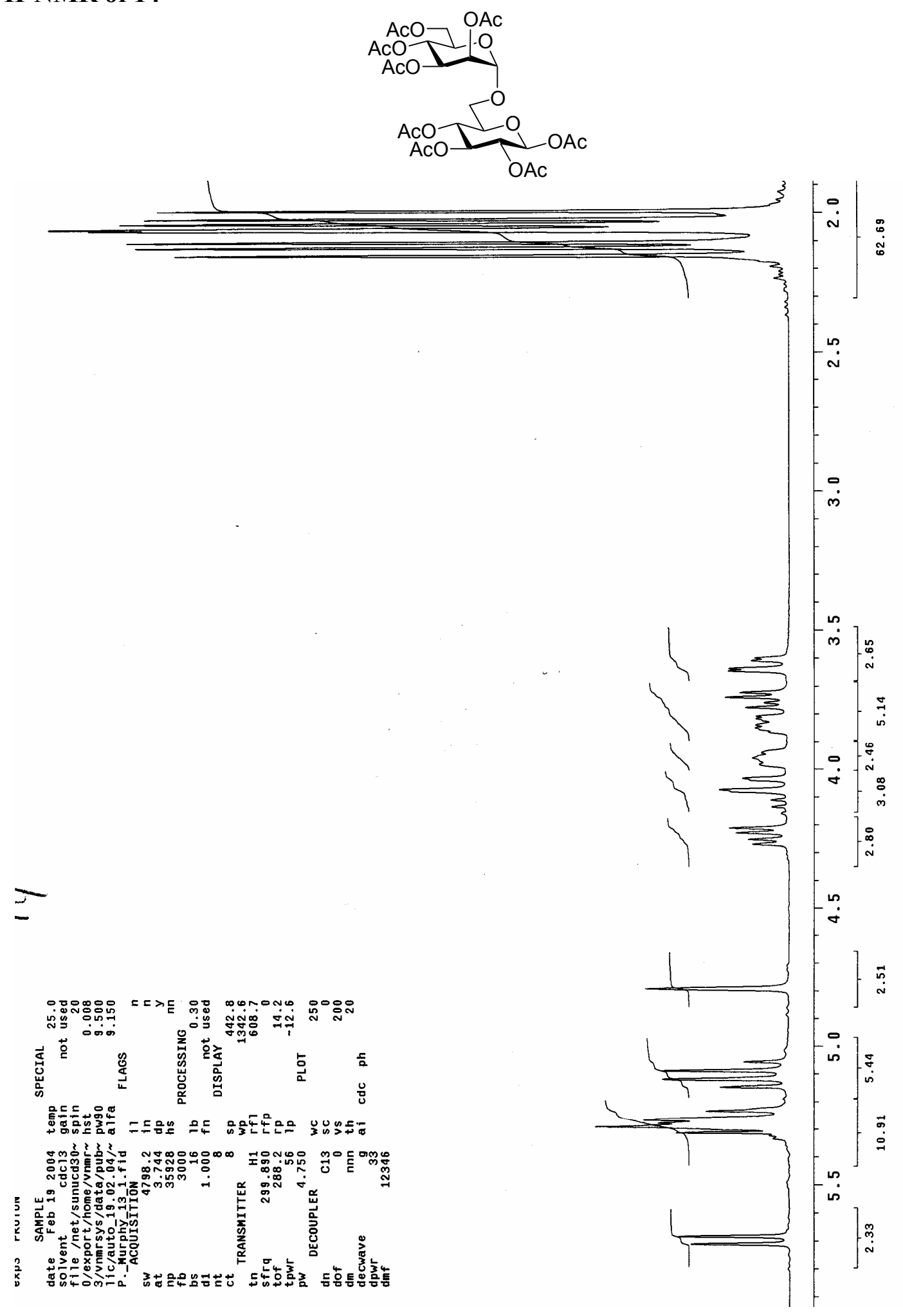




\section{${ }^{13}$ C-NMR of 14}
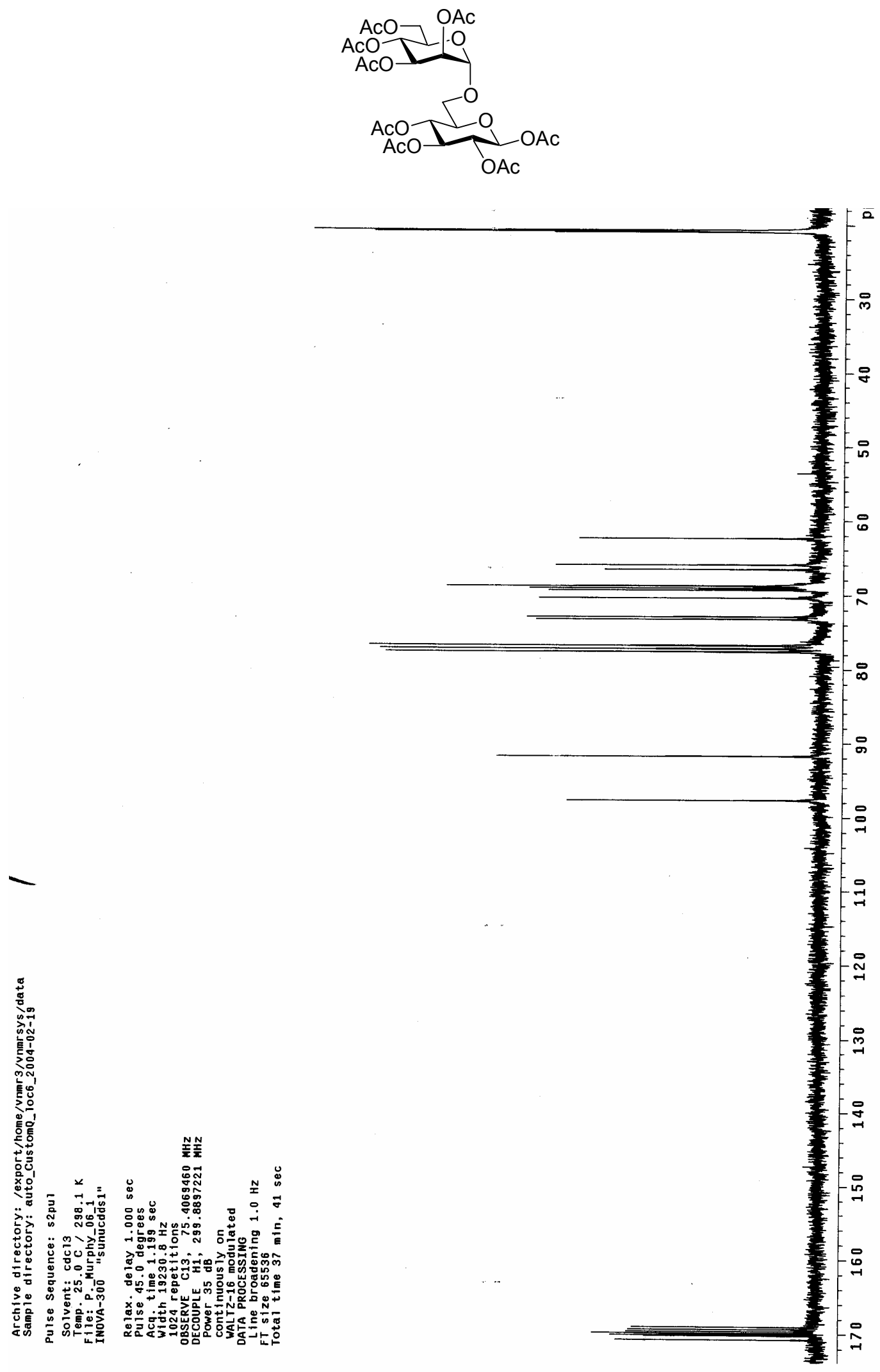


\section{${ }^{1}$ H-NMR of 15}
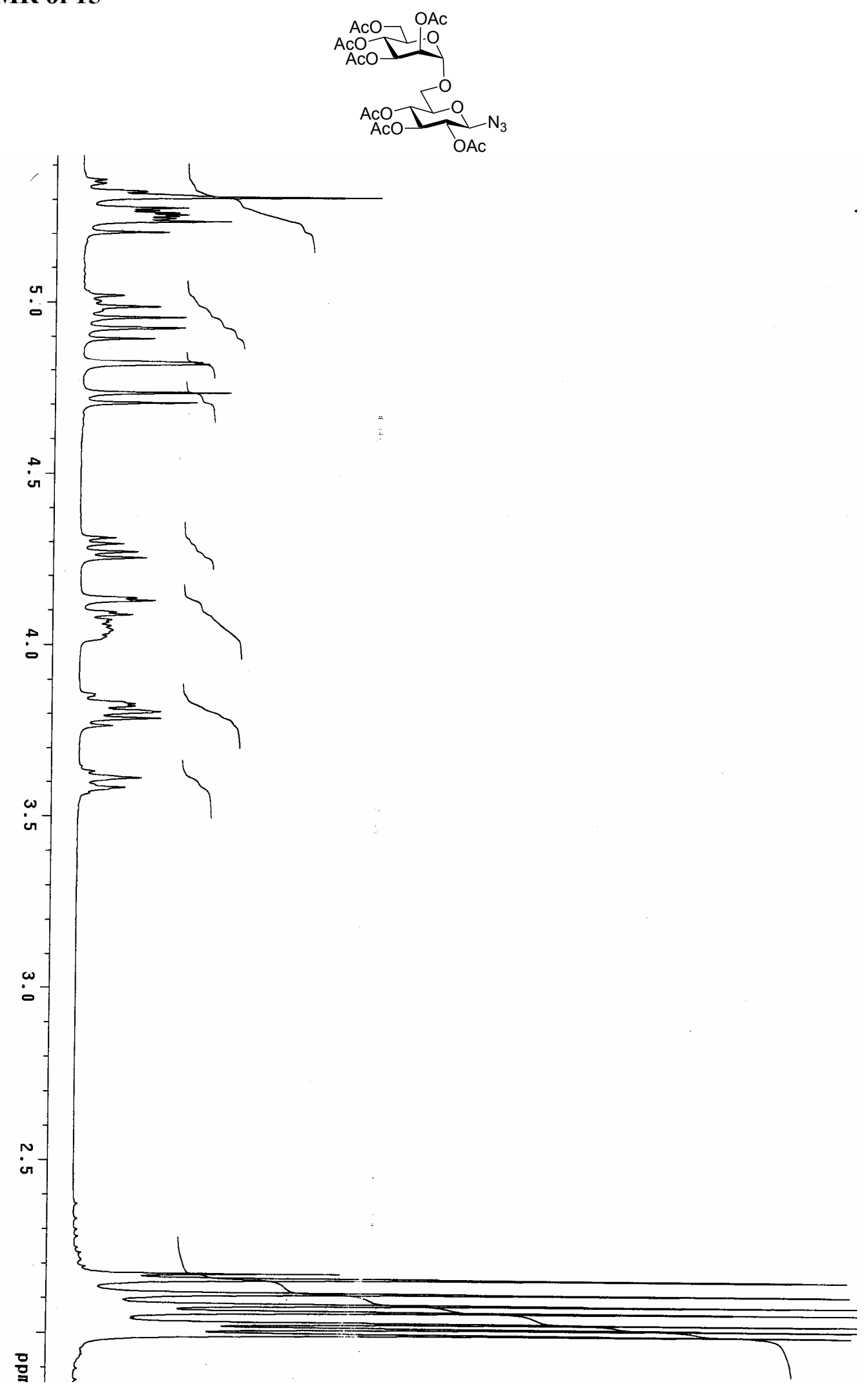


\section{${ }^{13}$ C-NMR of 15}
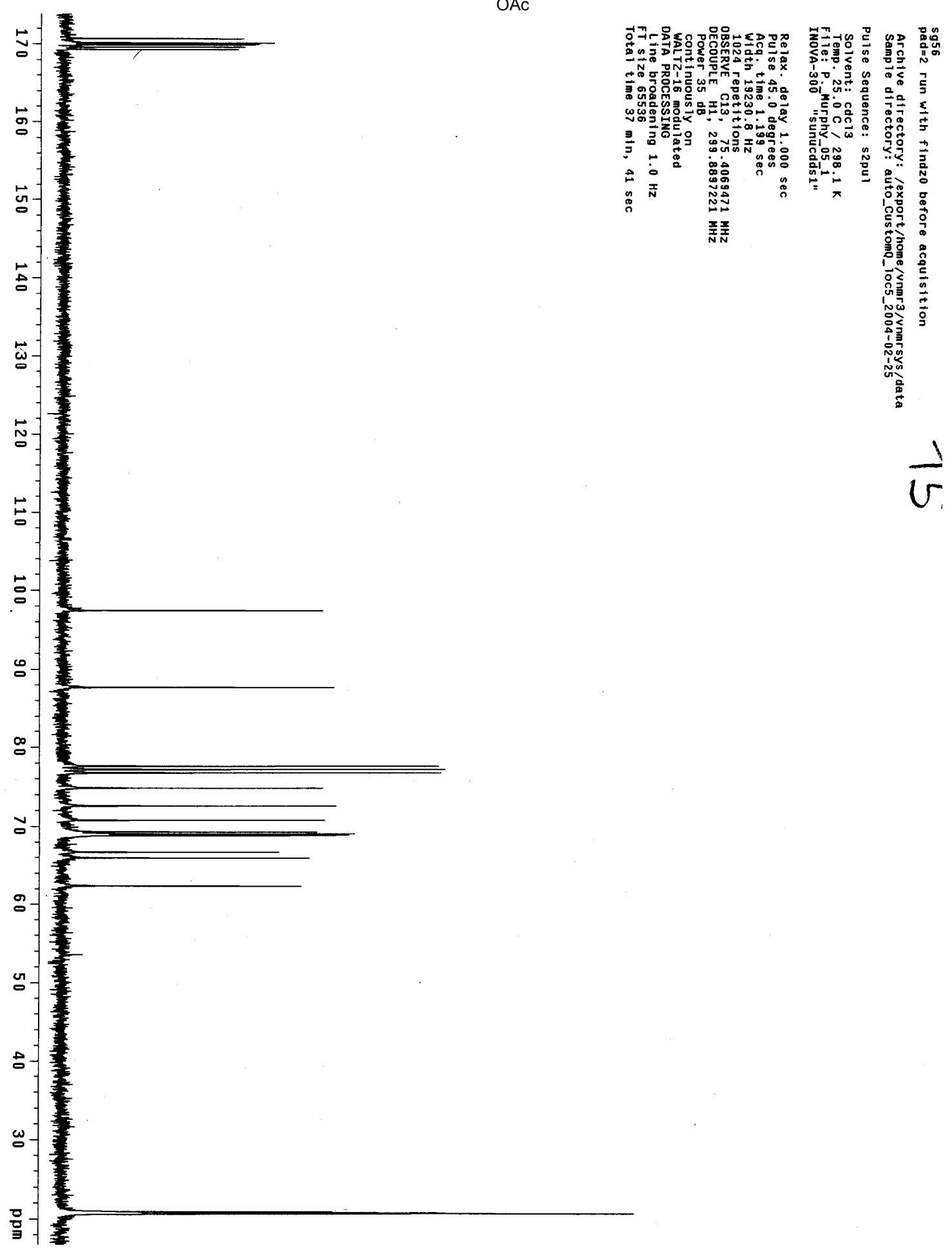


\section{${ }^{1}$ H-NMR of 16}
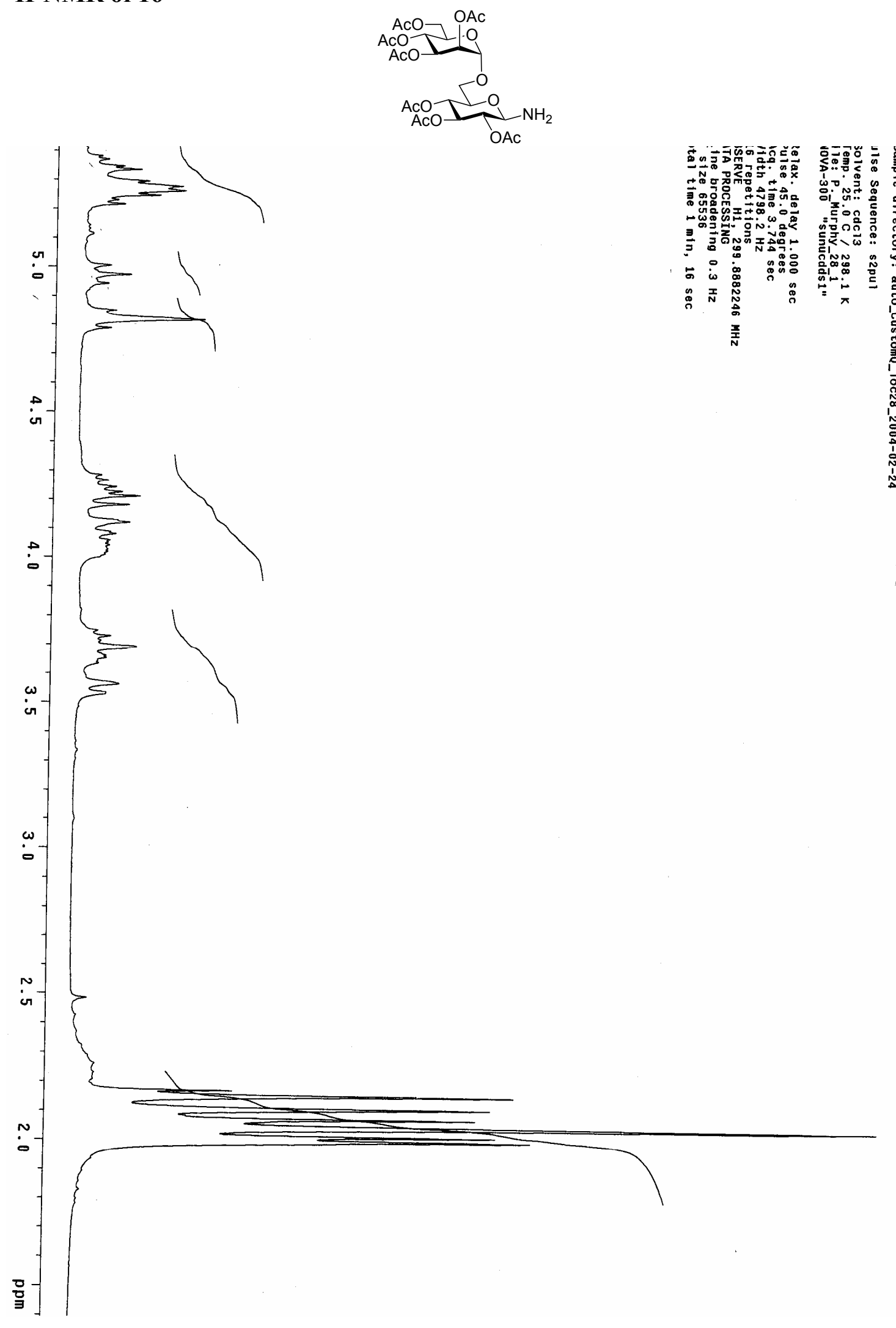


\section{${ }^{13}$ C-NMR of 16}

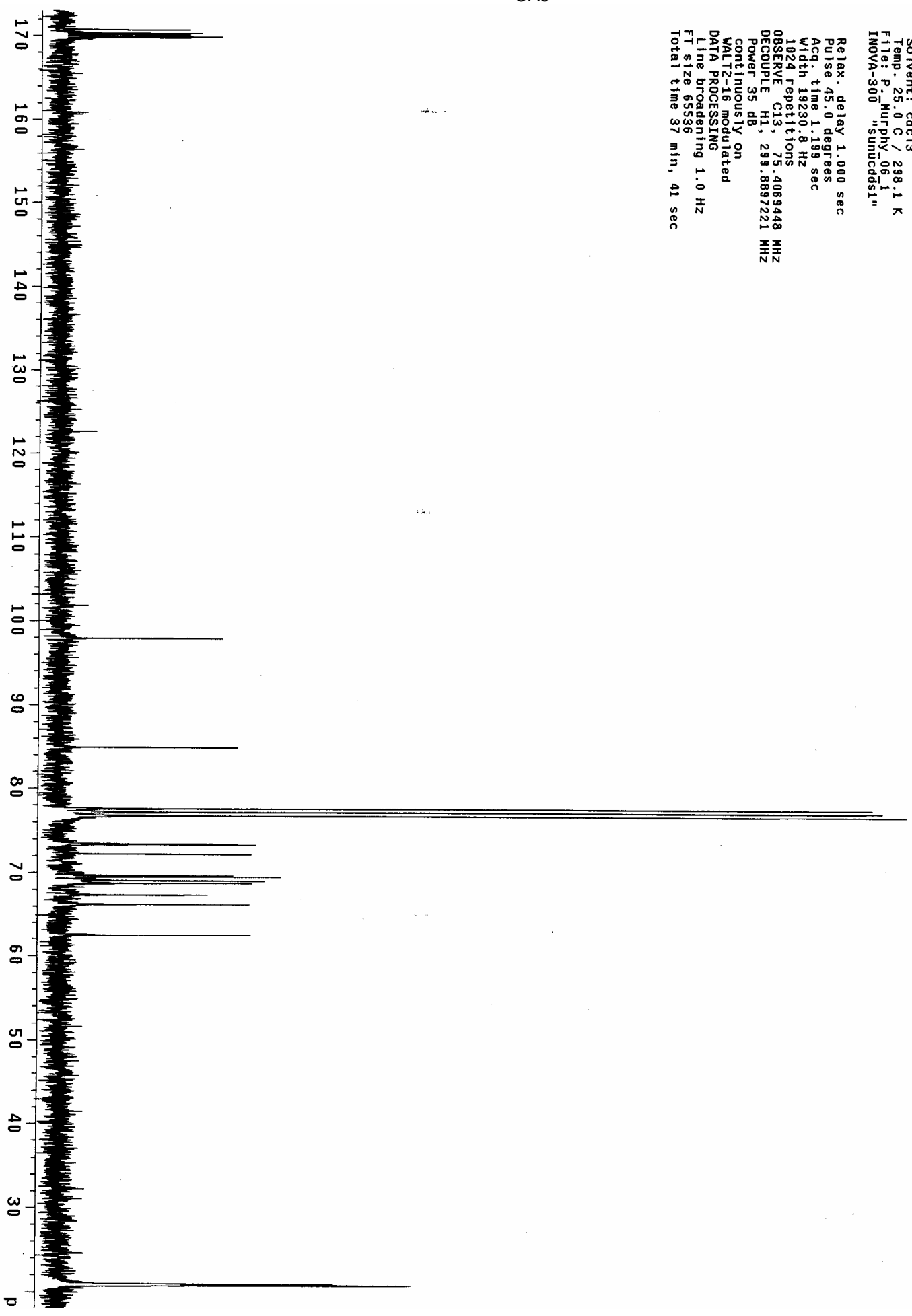




\section{${ }^{1}$ H-NMR of 17}
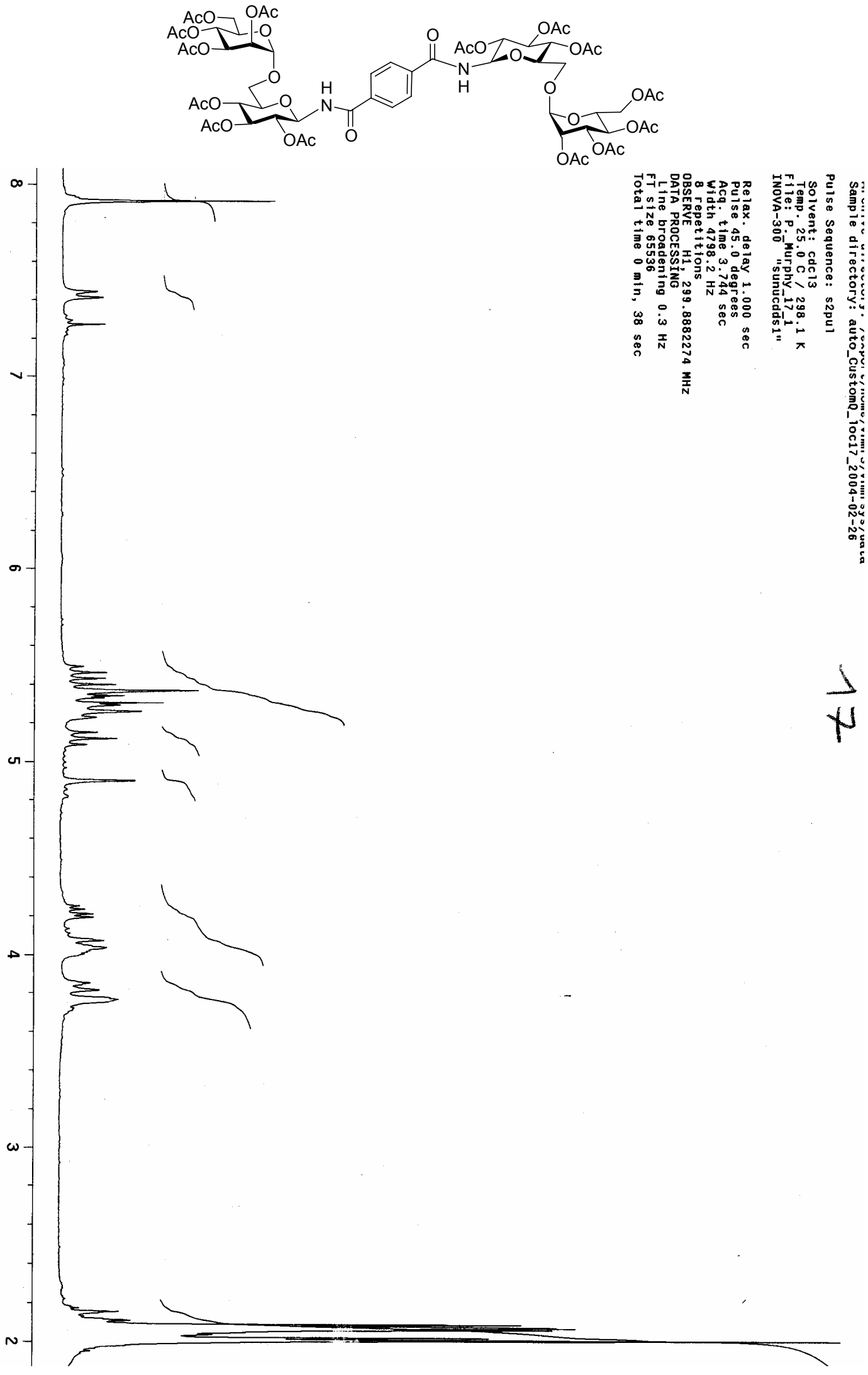


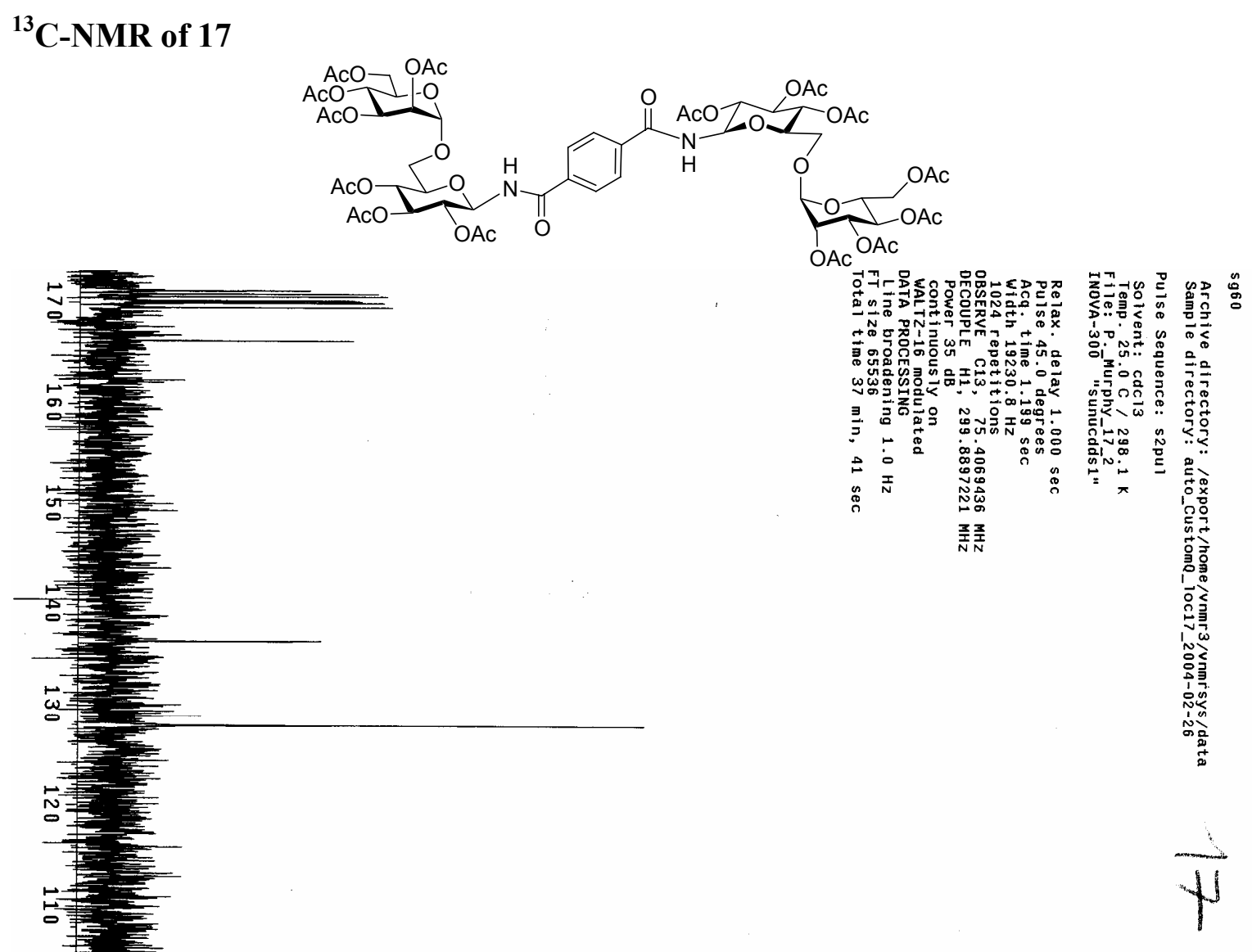




\section{${ }^{1}$ H-NMR of 19}

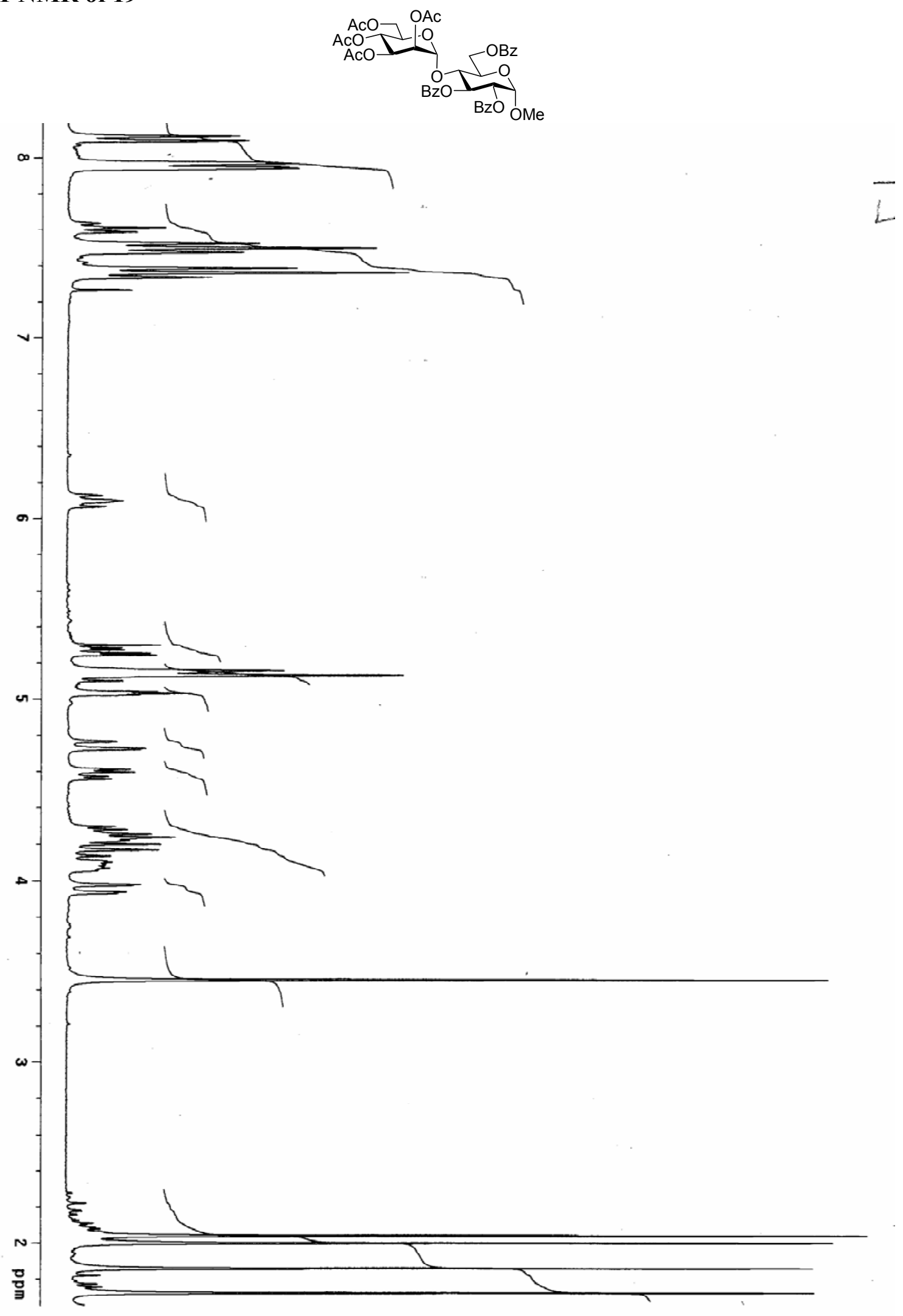




\section{${ }^{13}$ C-NMR of 19}

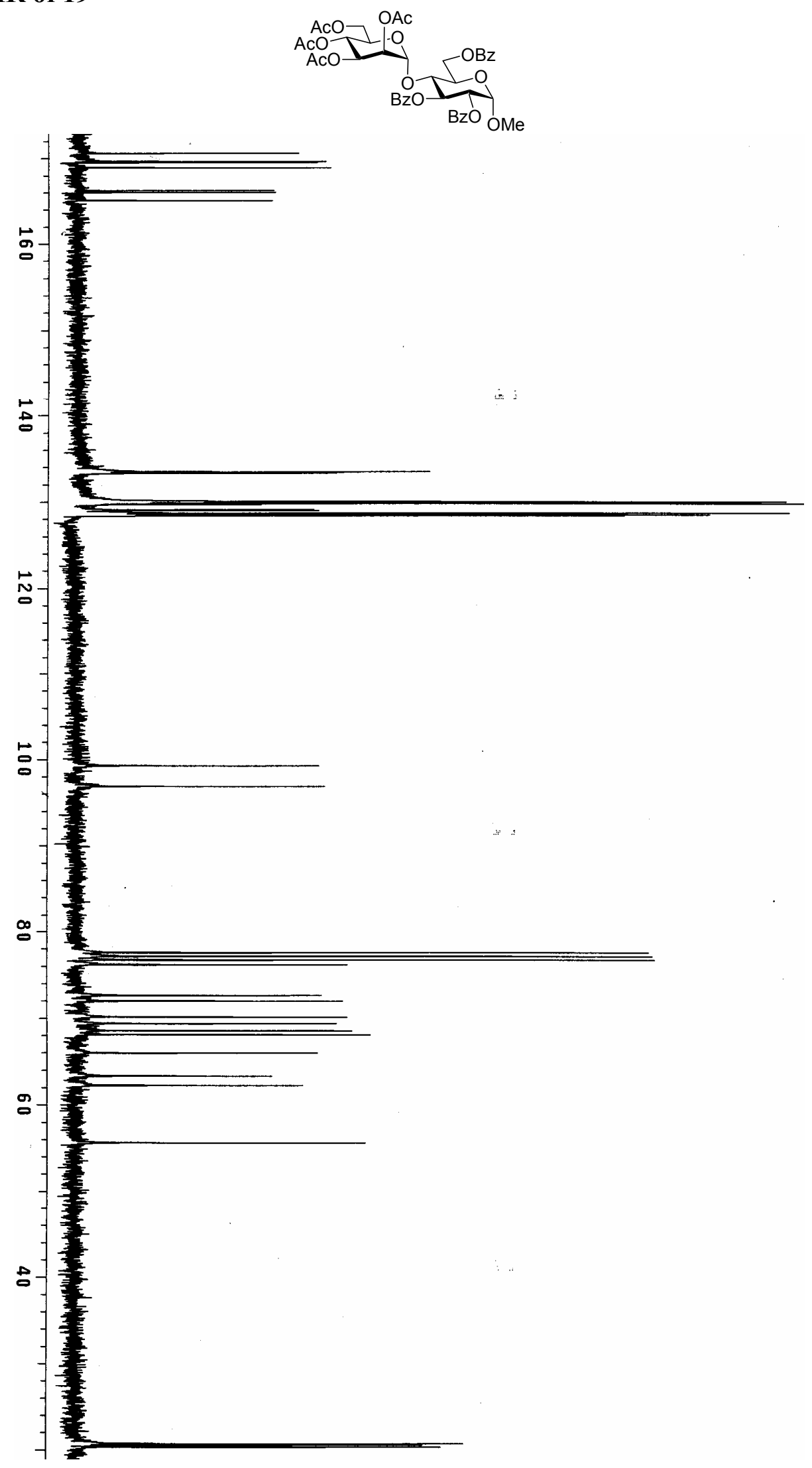




\section{${ }^{1}$ H-NMR of 20}

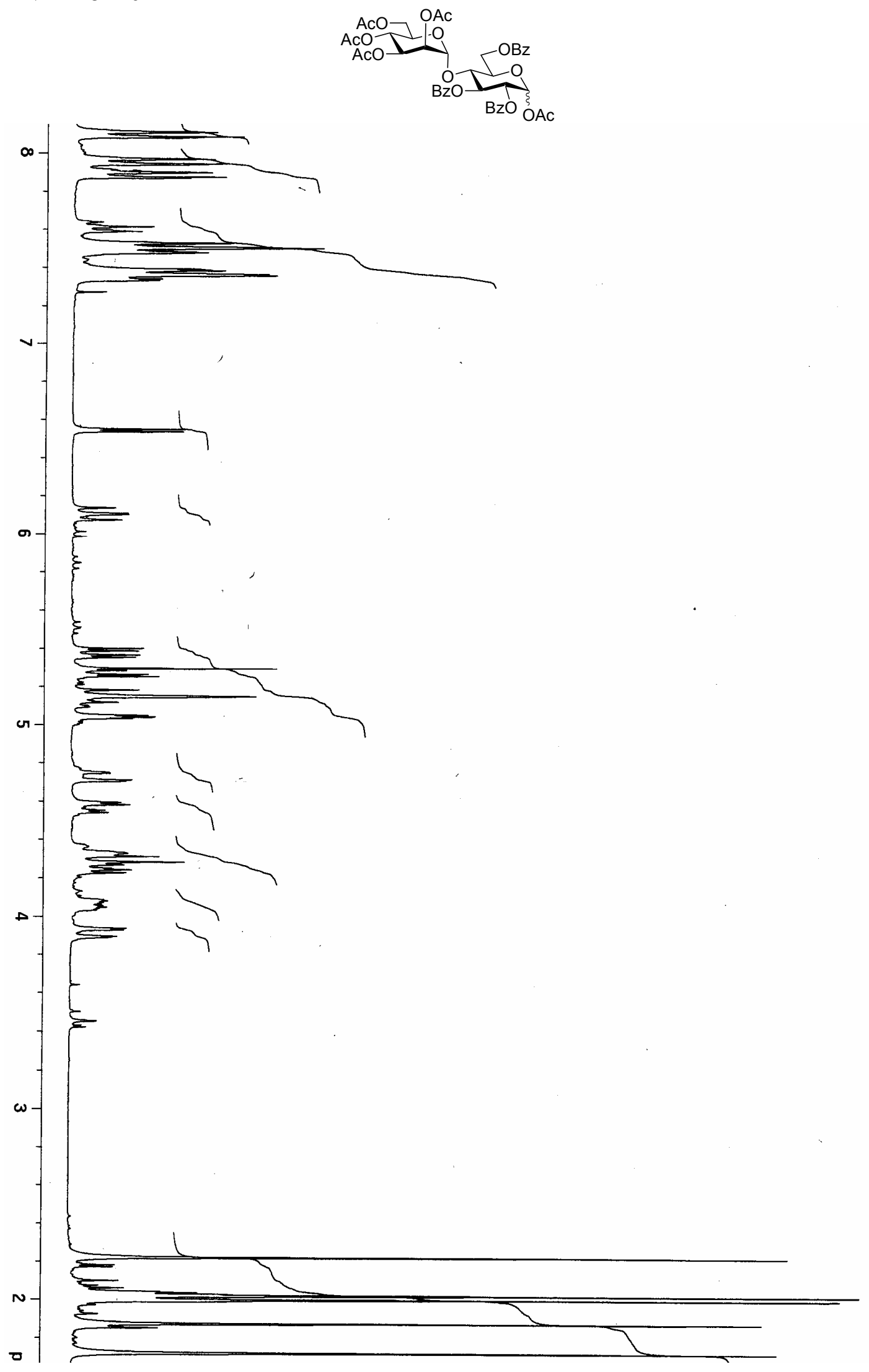




\section{${ }^{13}$ C-NMR of 20}
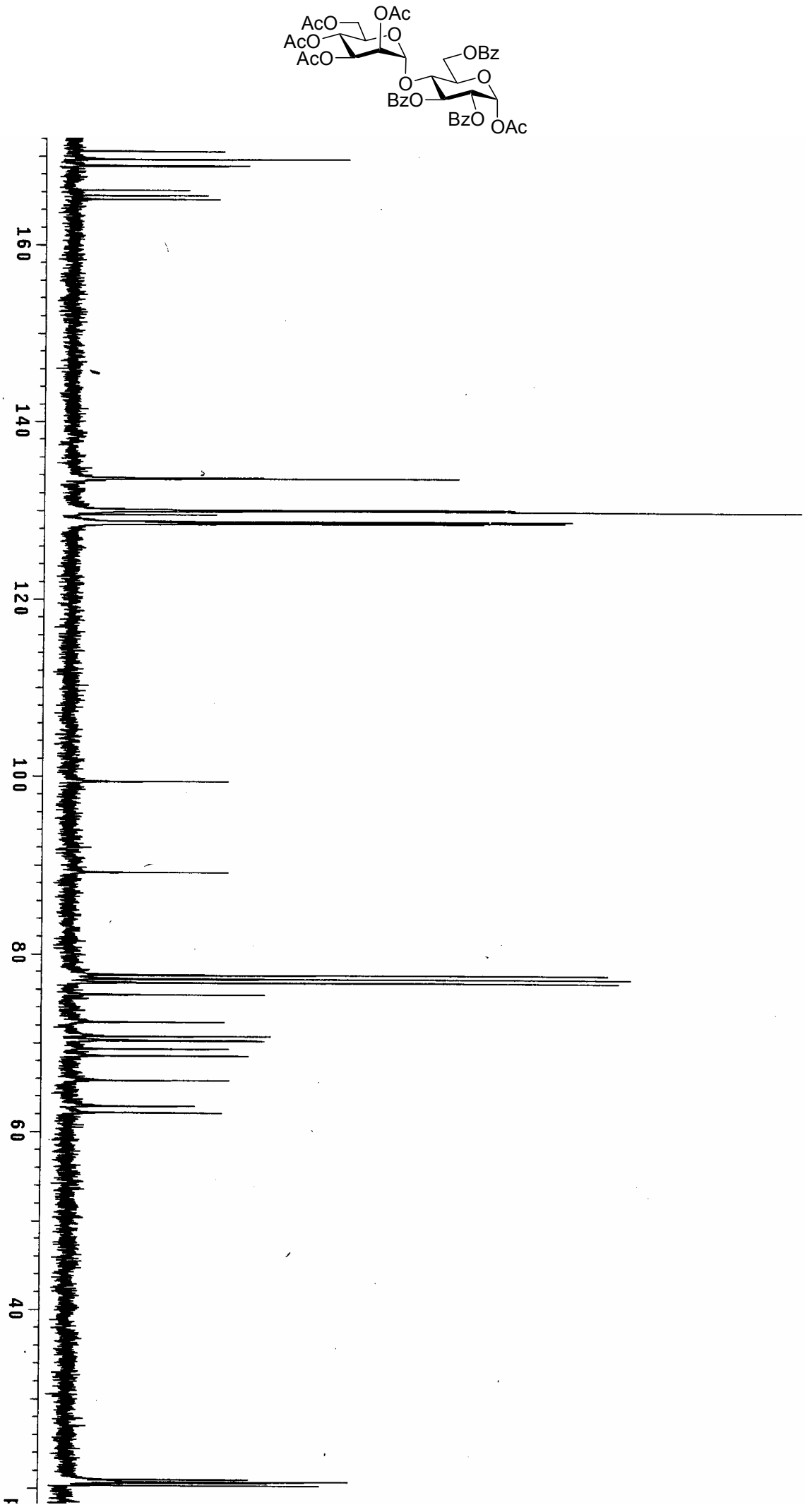


\section{${ }^{1}$ H-NMR}

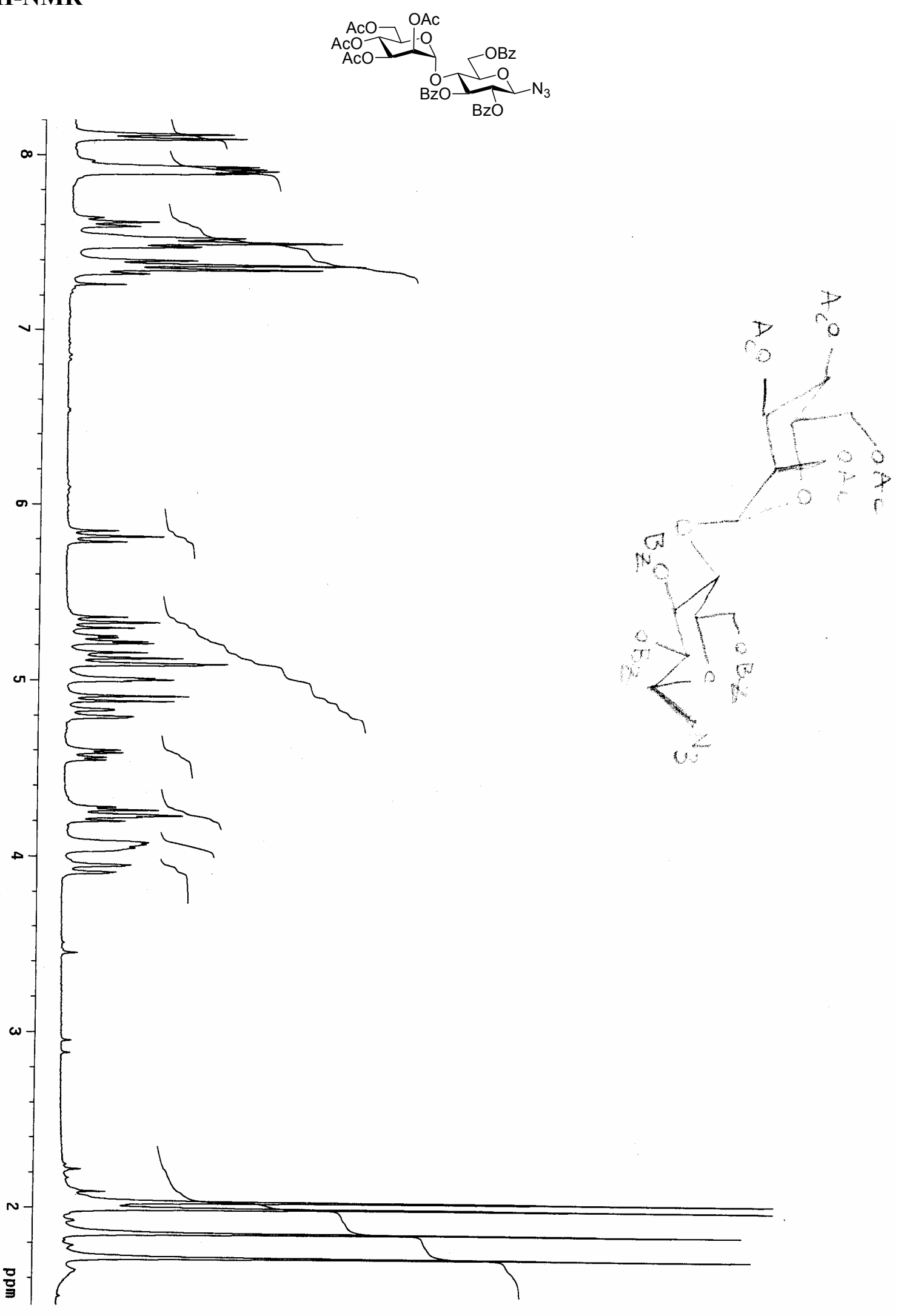


${ }^{13}$ C-NMR
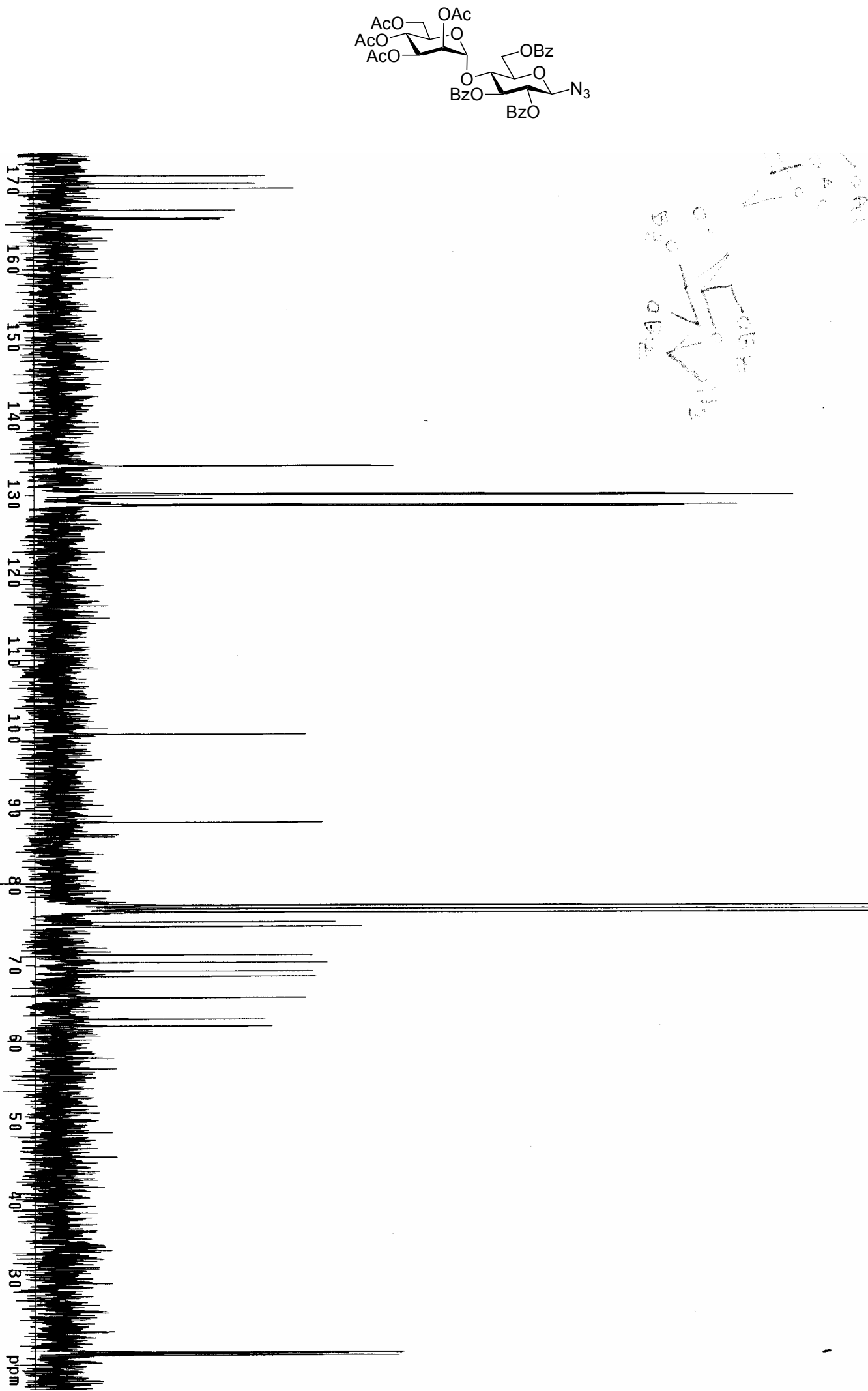


\section{${ }^{1}$ H-NMR of 21}

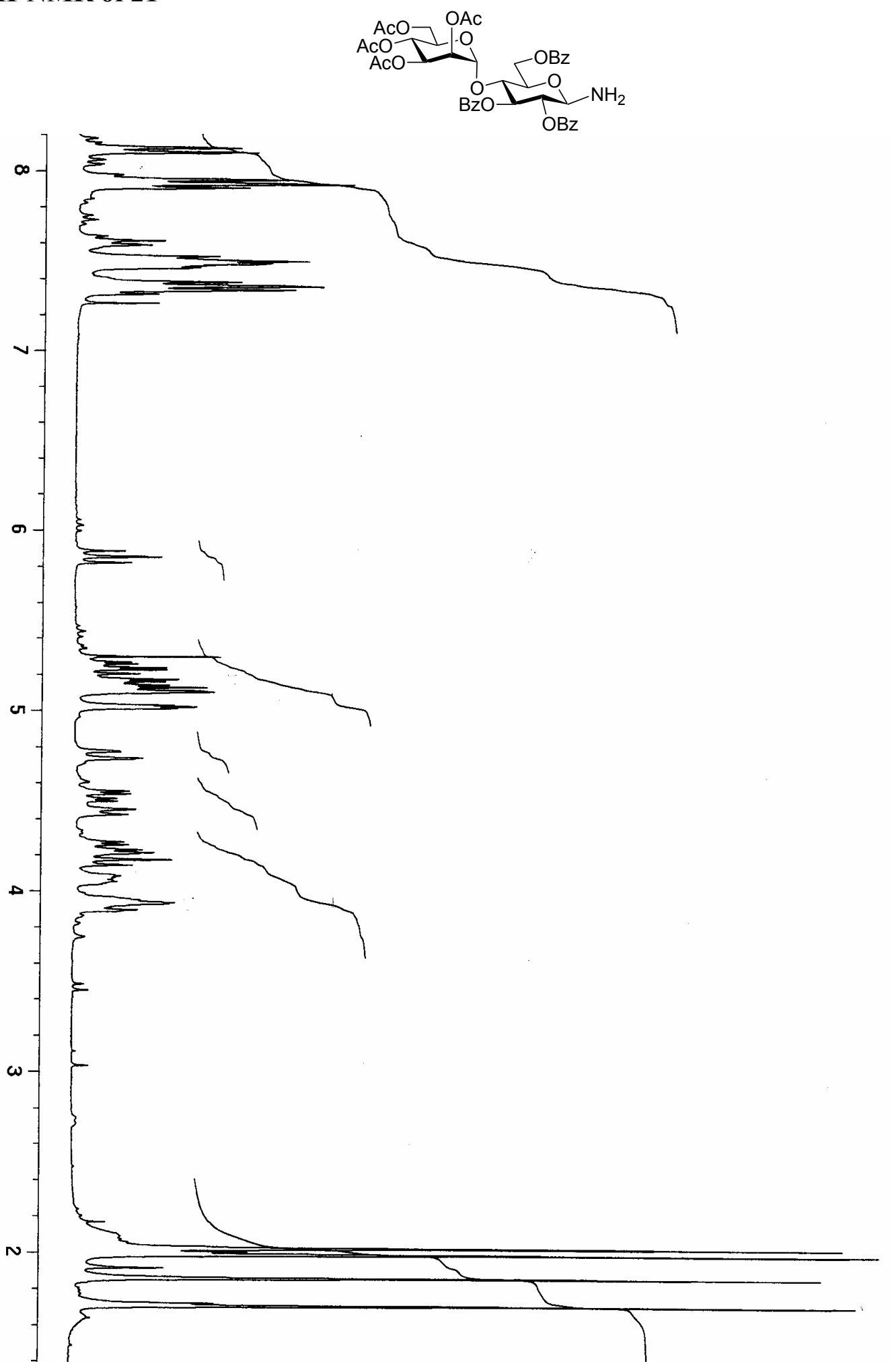




\section{${ }^{13}$ C-NMR of 21}
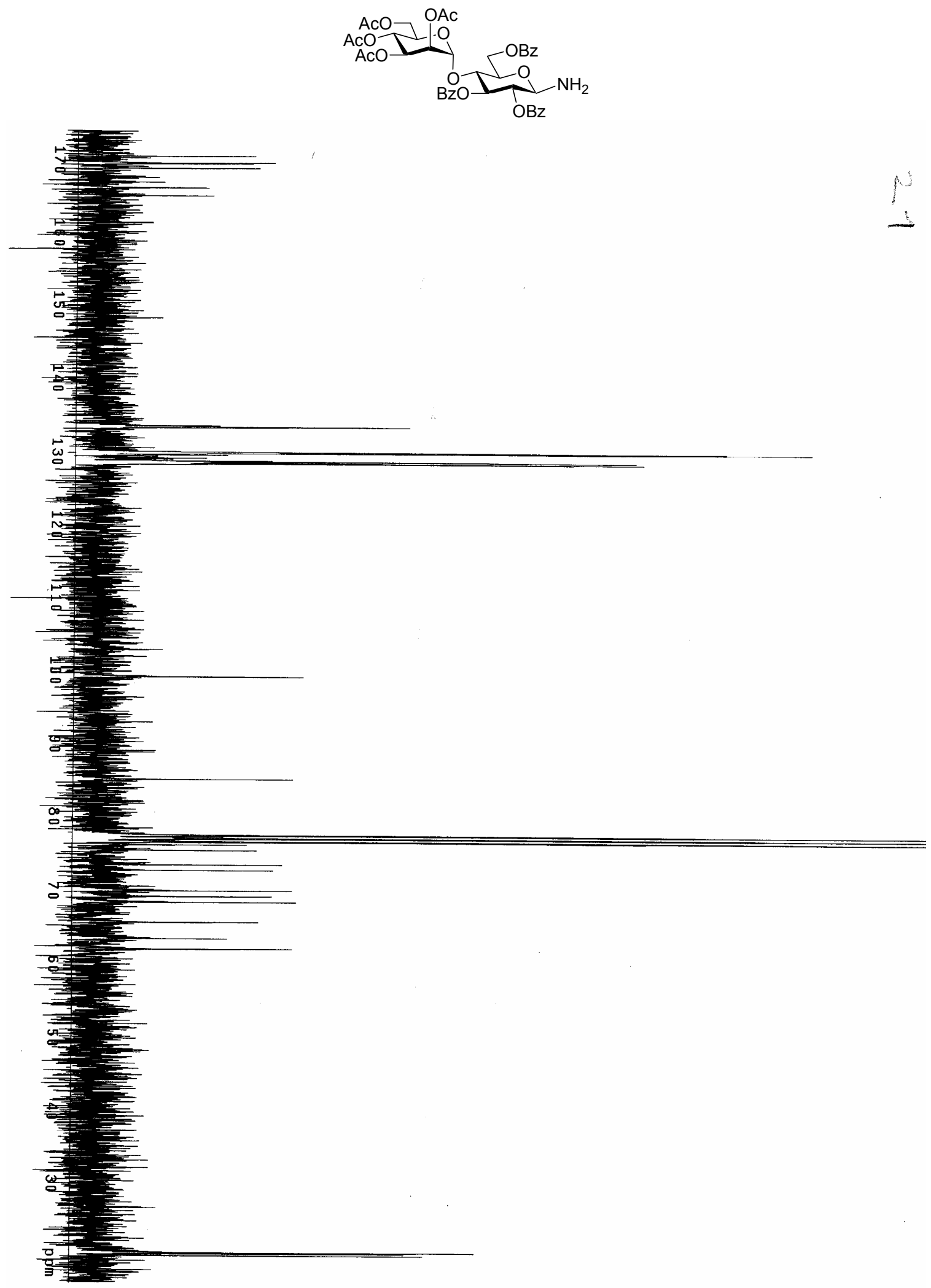


\section{${ }^{1}$ H-NMR}

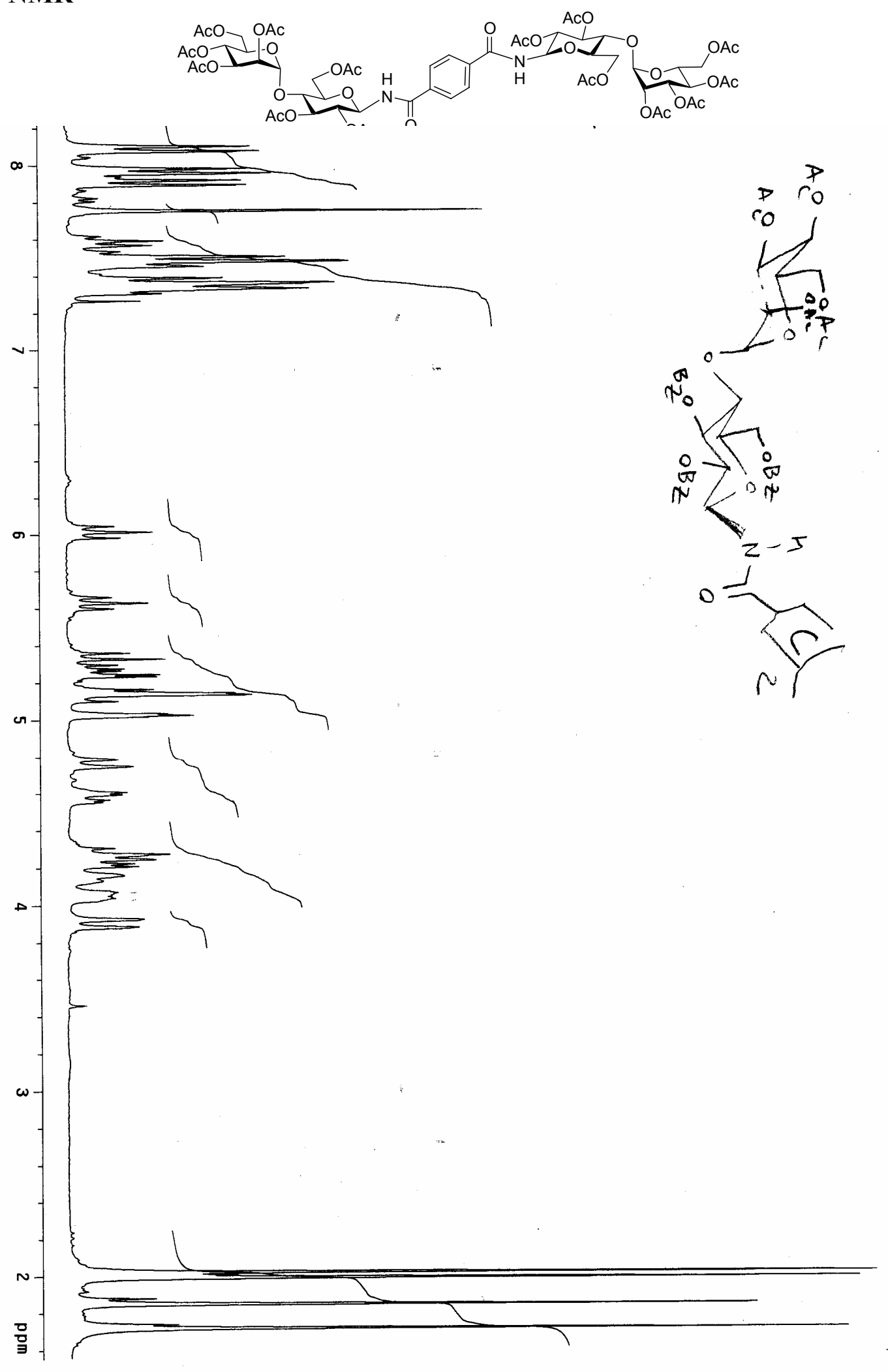




$$
E
$$




\section{${ }^{1}$ H-NMR of 22}

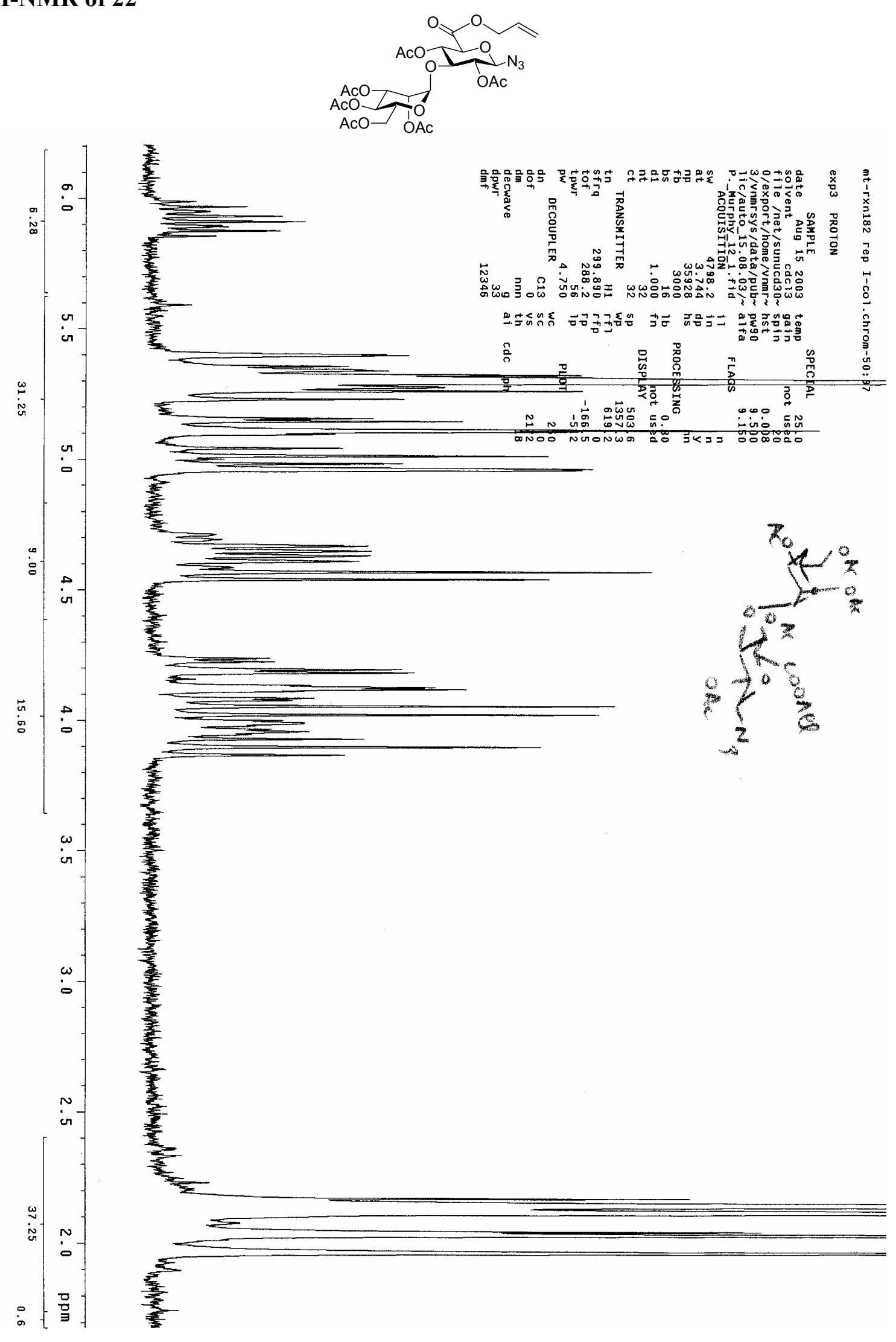




\section{${ }^{13}$ C-NMR of 22}
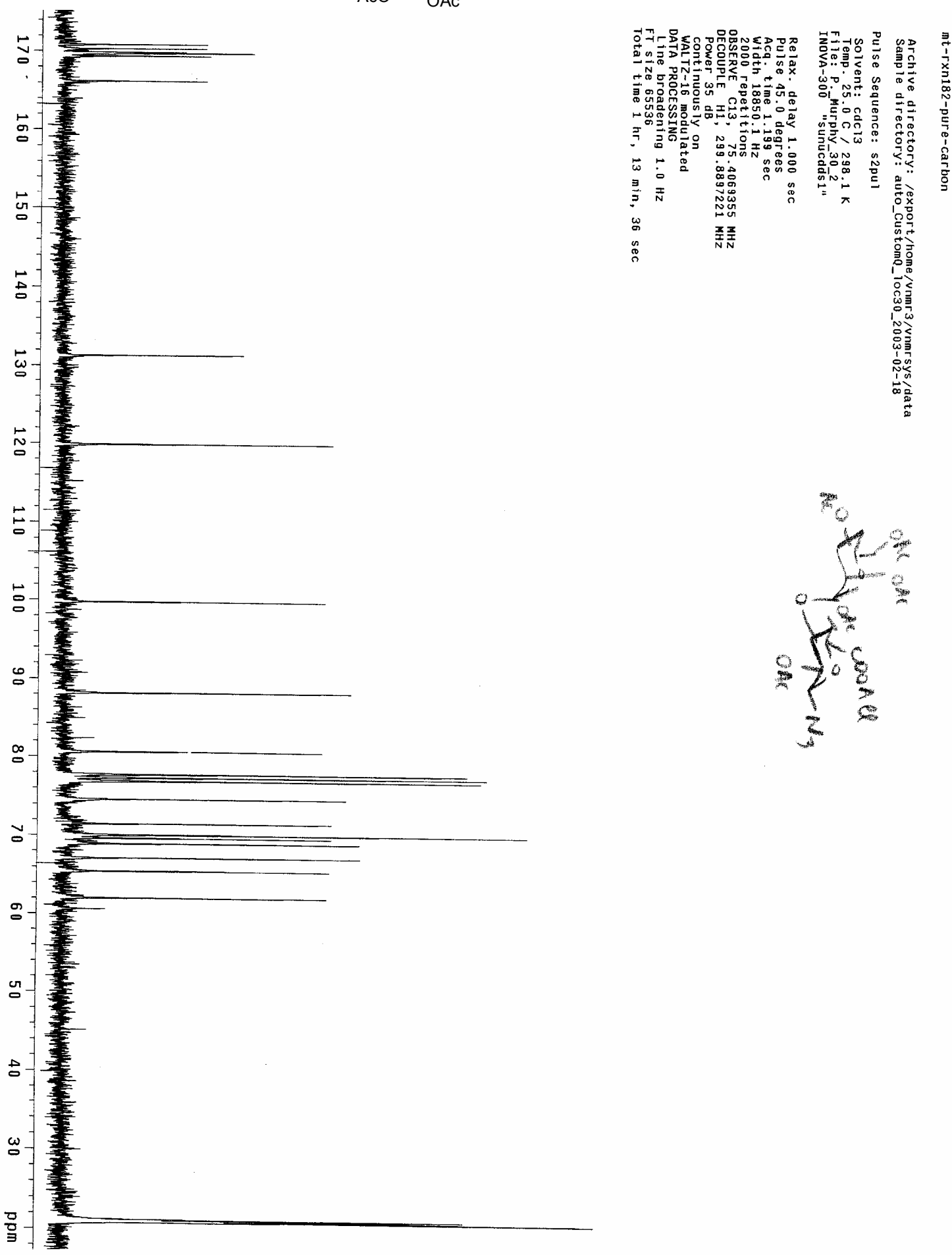


\section{${ }^{1}$ H-NMR of 23}

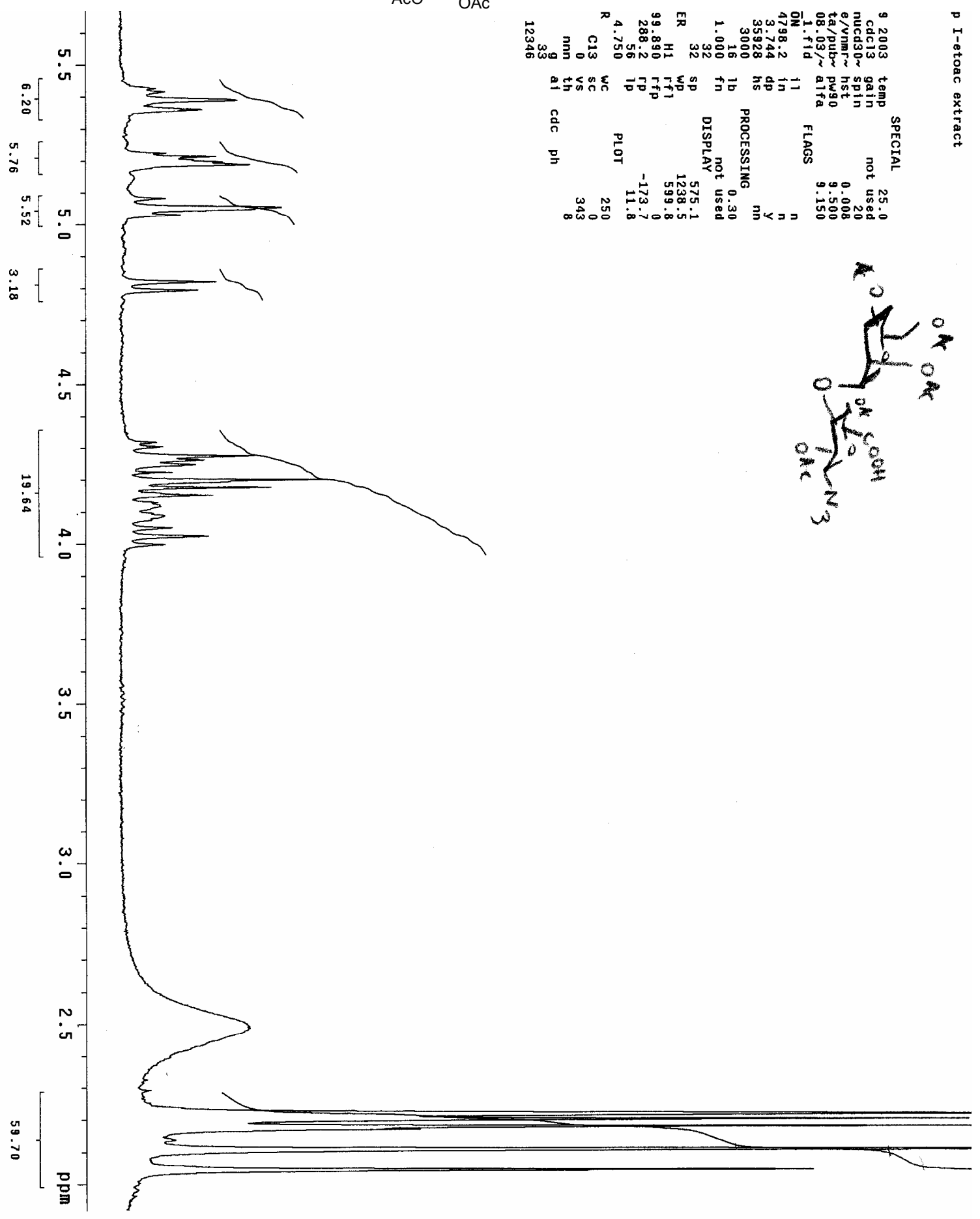




\section{${ }^{13}$ C-NMR of 23}

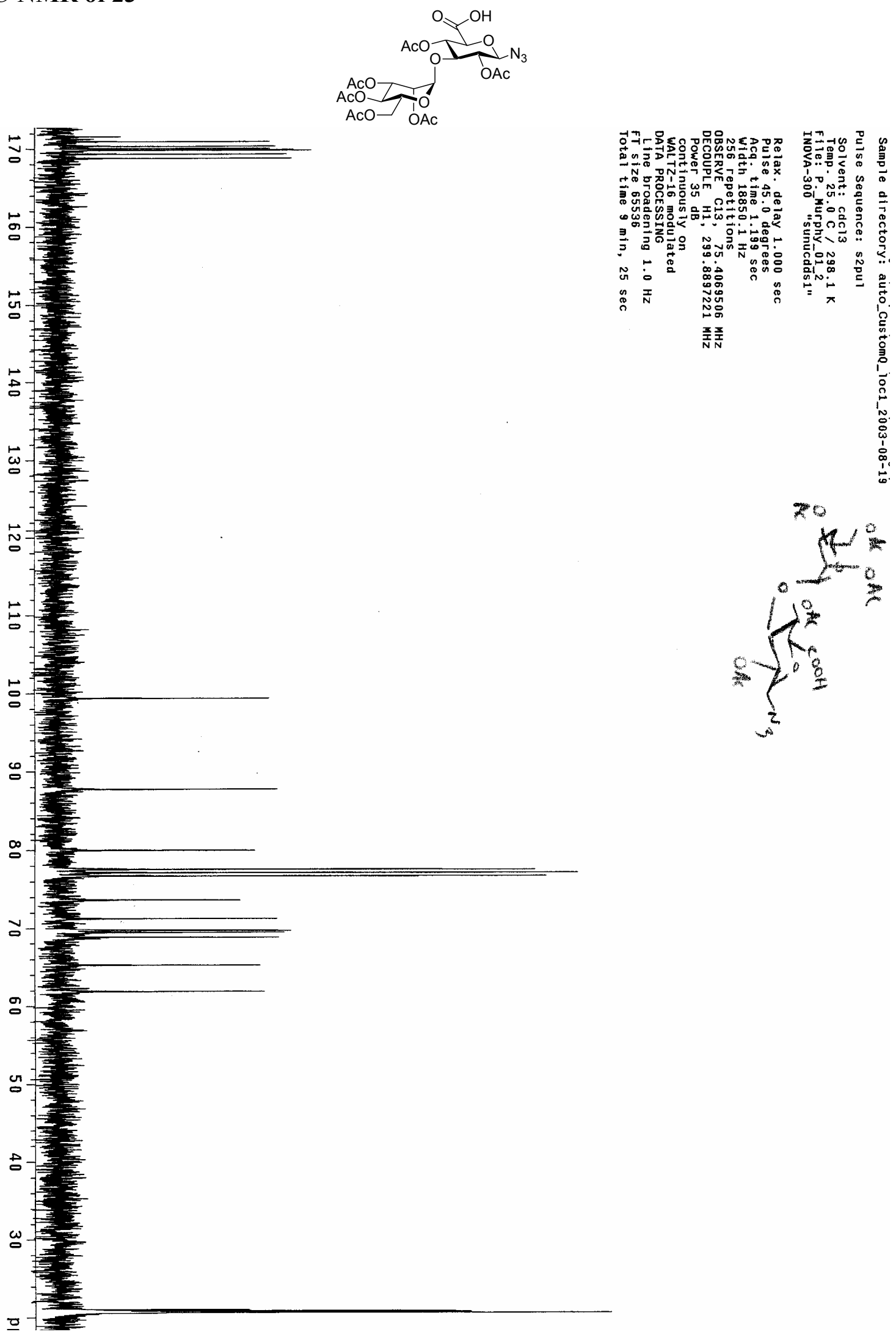




\section{Data from analysis of the stochastic dynamics simulations of 2-4}

\section{Glycosidic torsion analysis.}

The glycosidic torsion angles of sampled structures were consistent with those found as low energy structures $(<10 \mathrm{~kJ} / \mathrm{mol})$ above global minimum structure from conformational searches using SUMM method in Macromodel 8.5 for model disaccharides (OPLS-AA force field, GB/SA solvent continuum for water).

\section{A. Glycosidic torsional profile for $\mathbf{2}$ for $\mathbf{1 0 0 0}$ sampled structures}

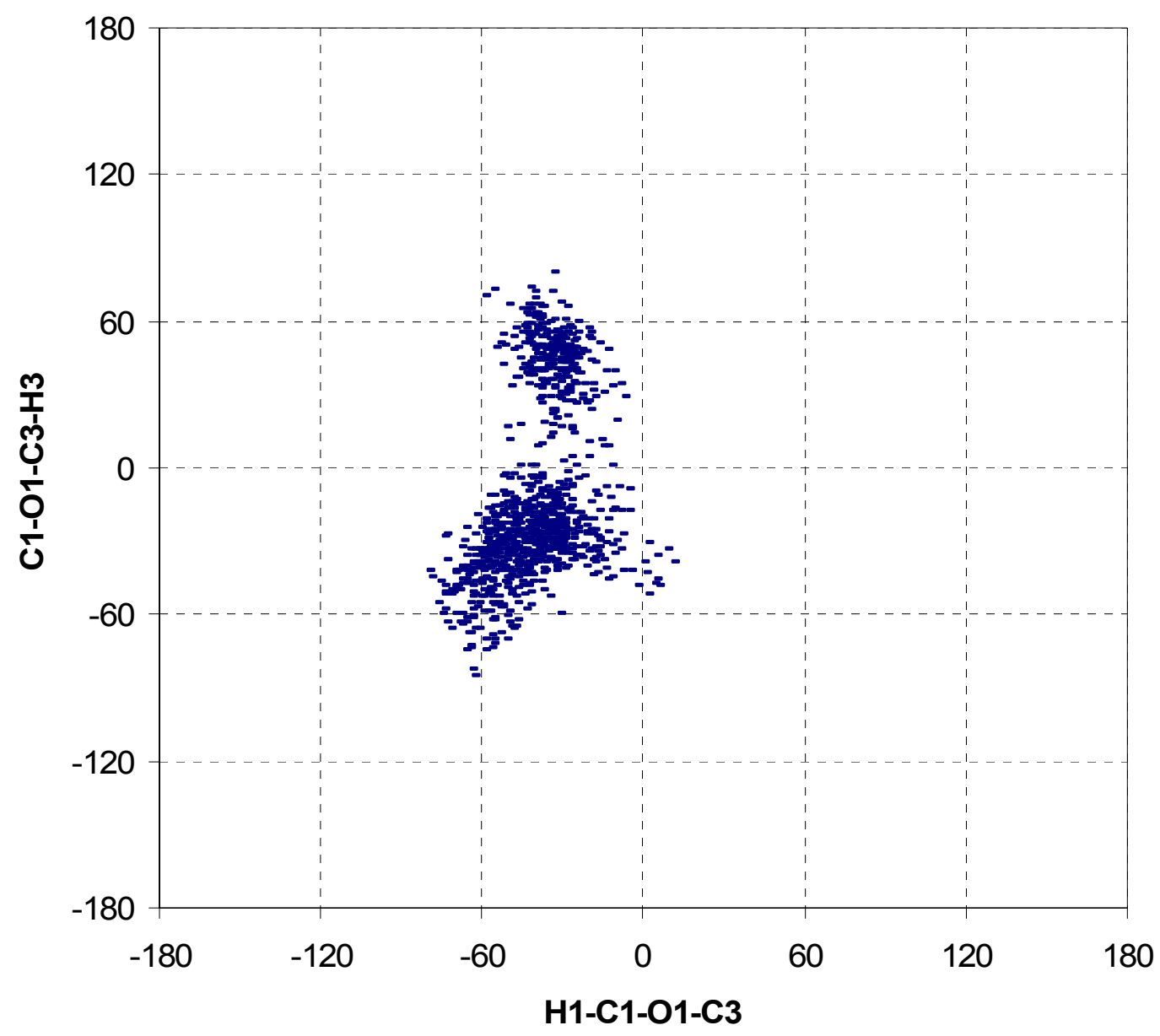


2. Glycosidic torsional profile for $\mathbf{3}$ for $\mathbf{1 0 0 0}$ sampled structures

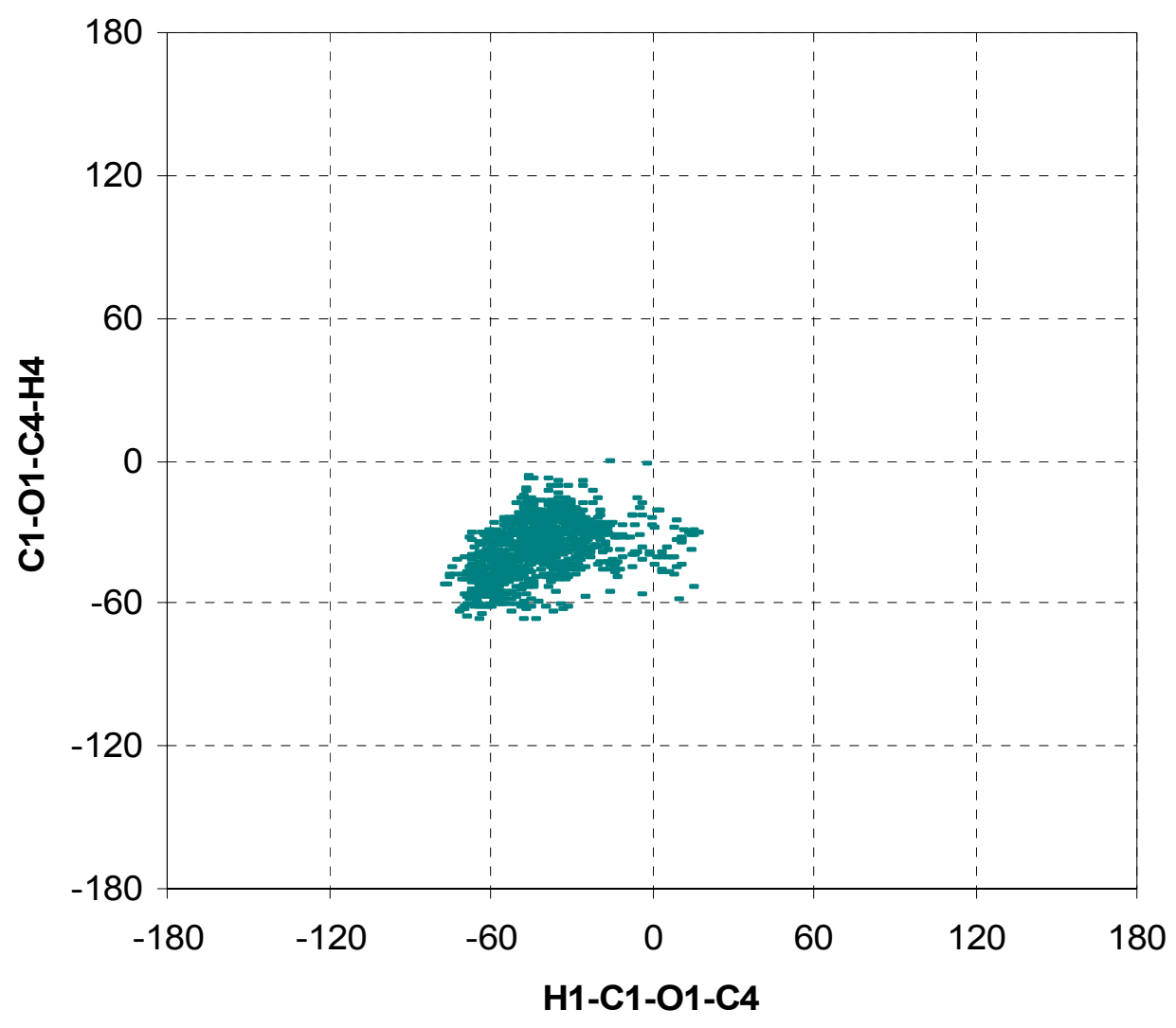


3. Glycosidic torsional profiles for 4 (1000 sampled structures)
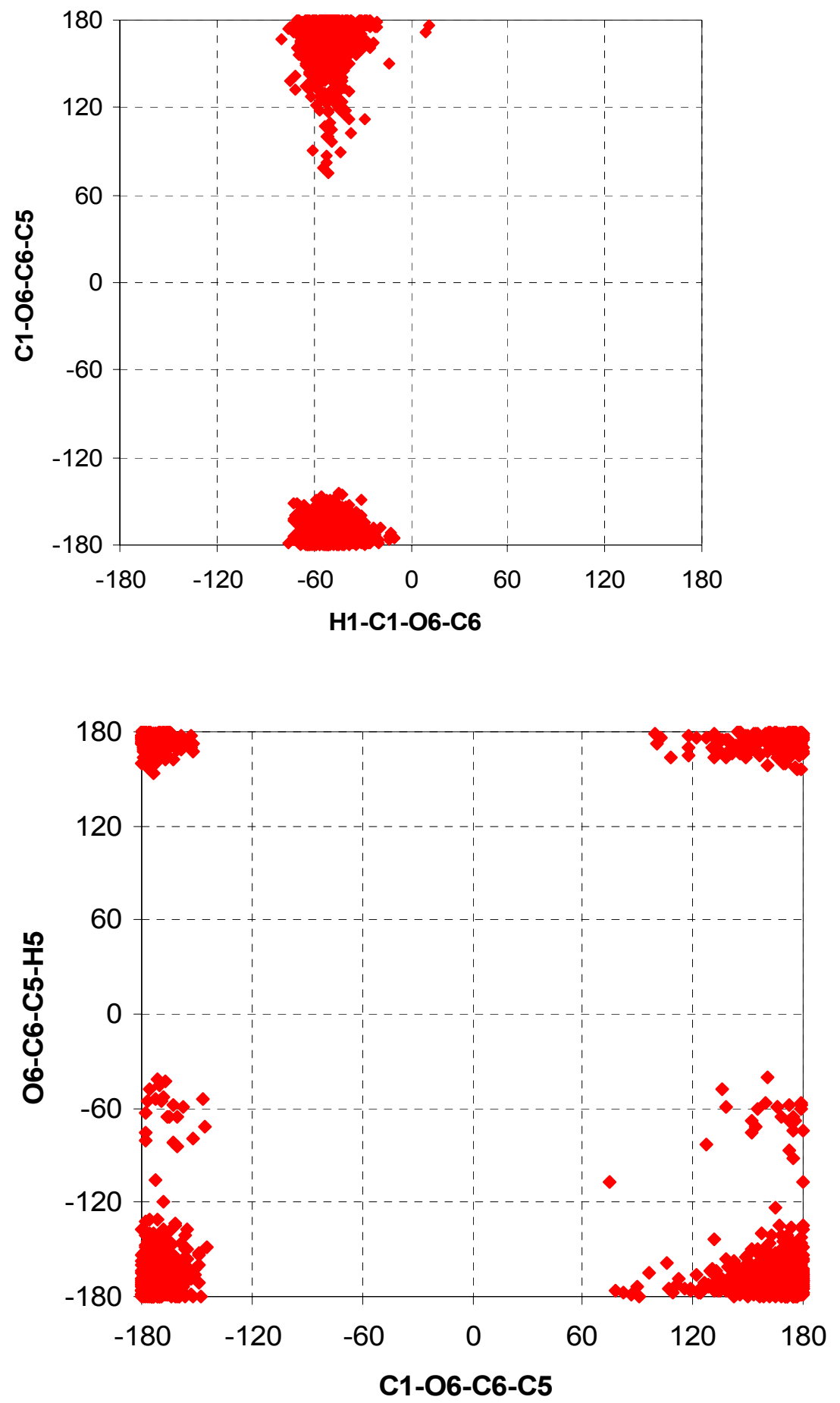
4. Glycosidic torsion analysis from conformational searching techniques for model disaccharides<smiles>O=C(NC(O)C(O)C(O)COC1C(O)C(O)C2(CO)COC1C(O)C2O)c1ccccc1</smiles>

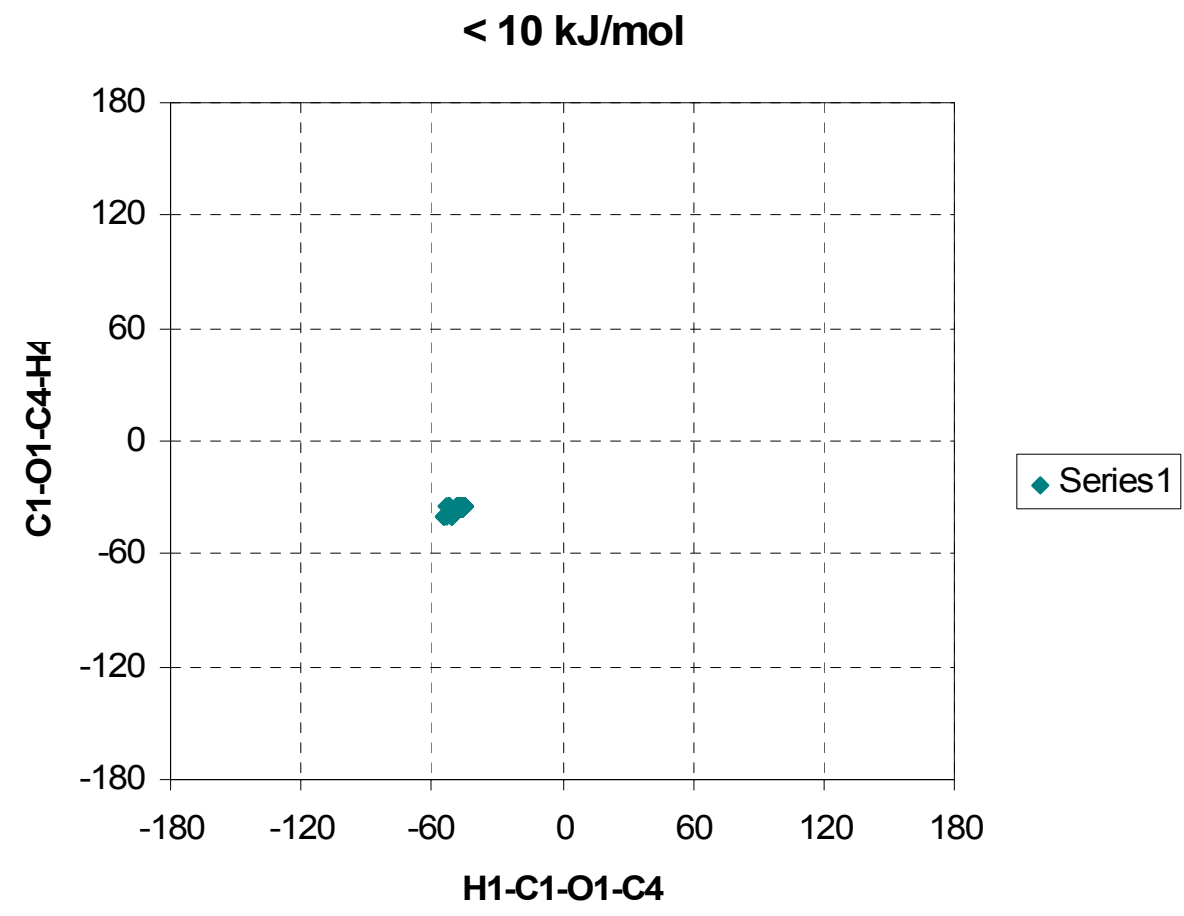



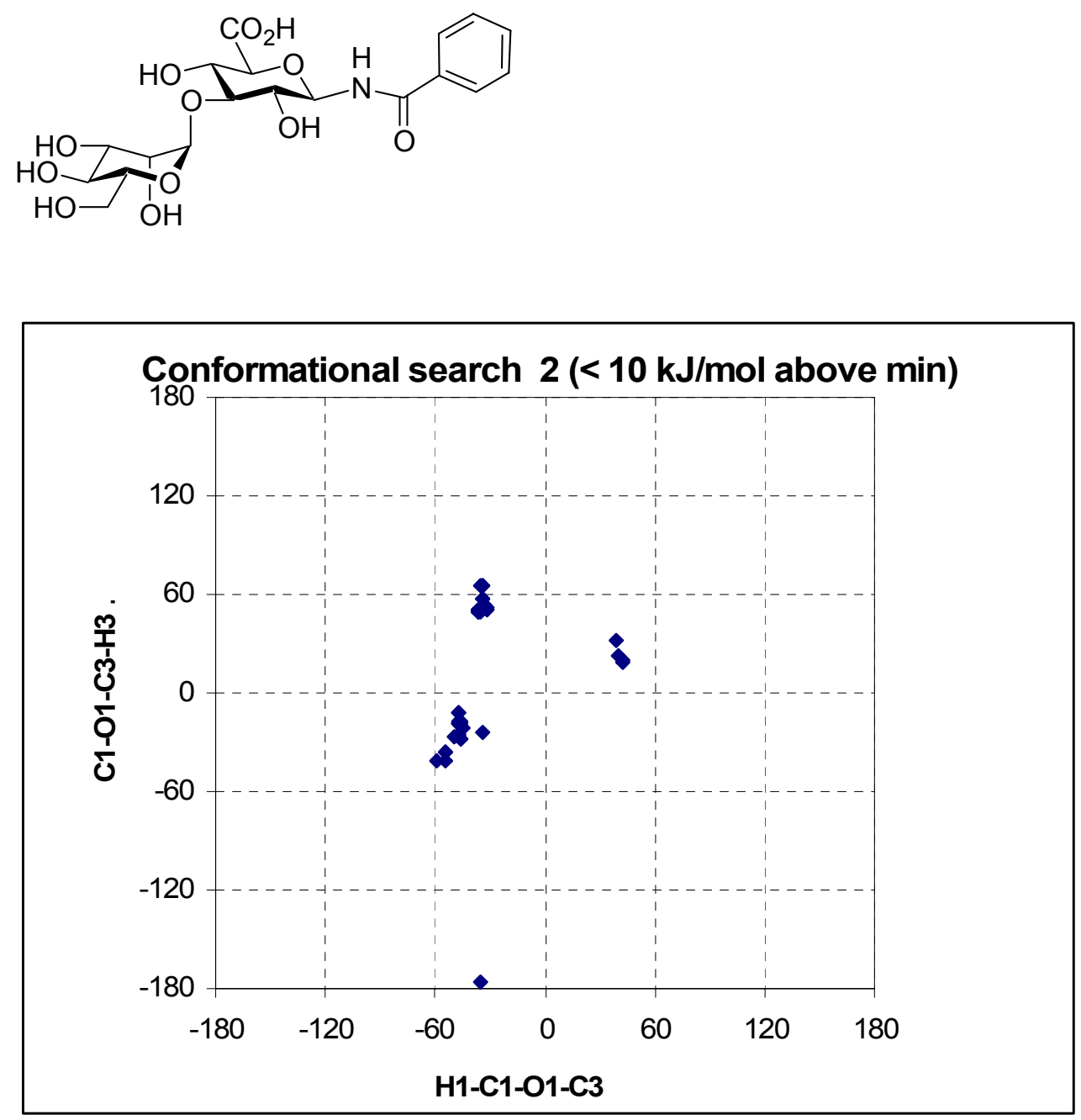

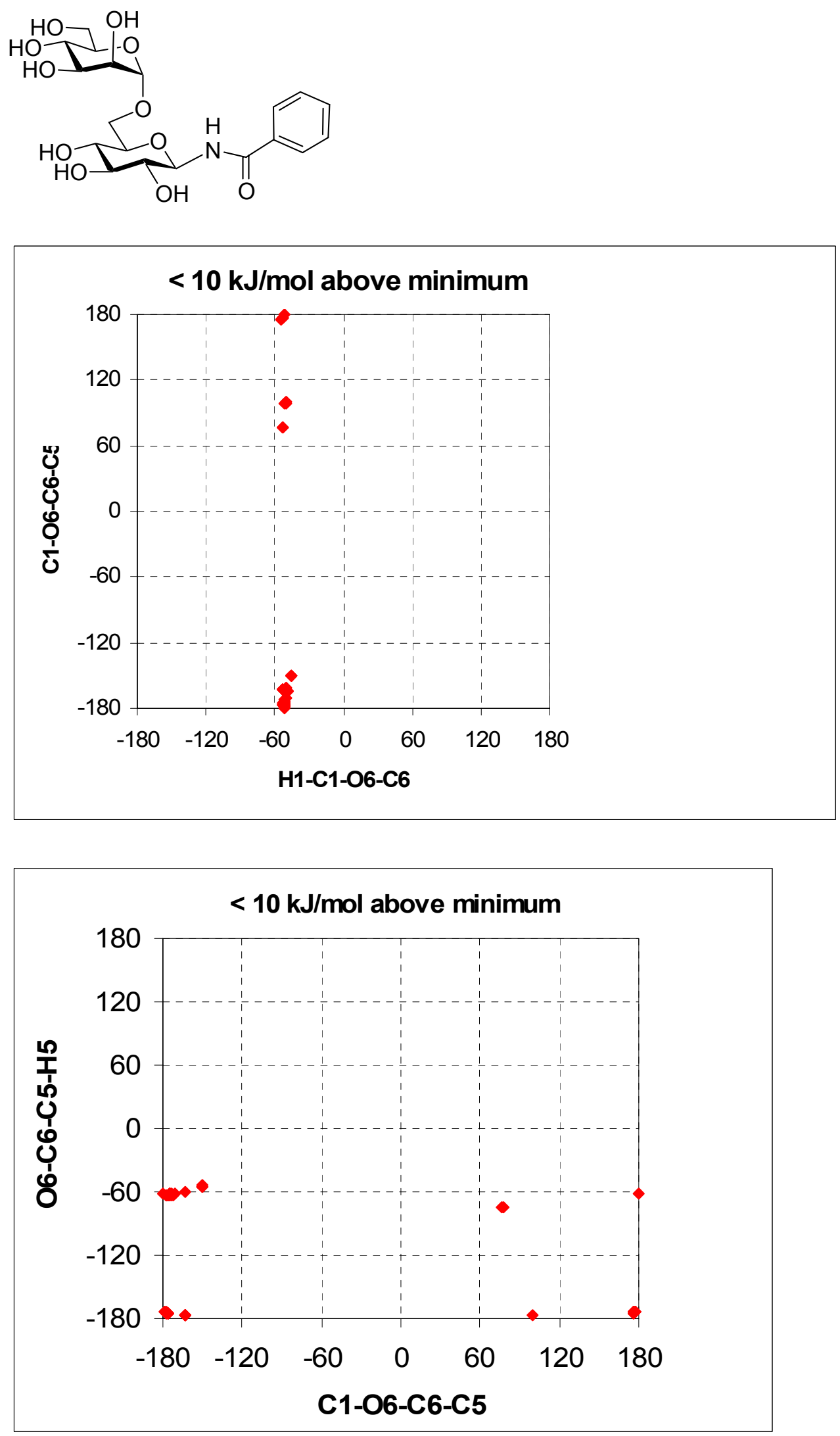


\section{Mannose Orientation Profiles as Figure 2 in Manuscript}

\section{Compound 2}

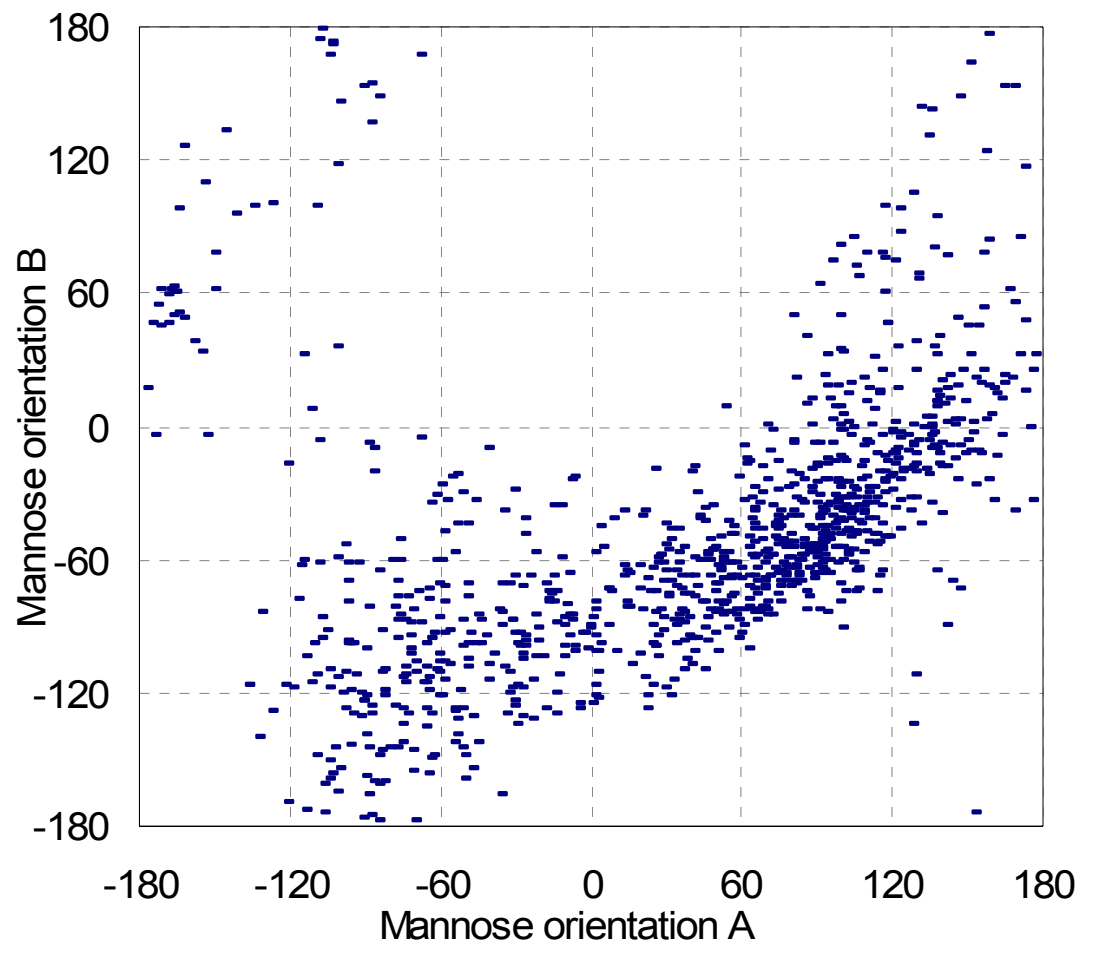

\section{Compound 3}

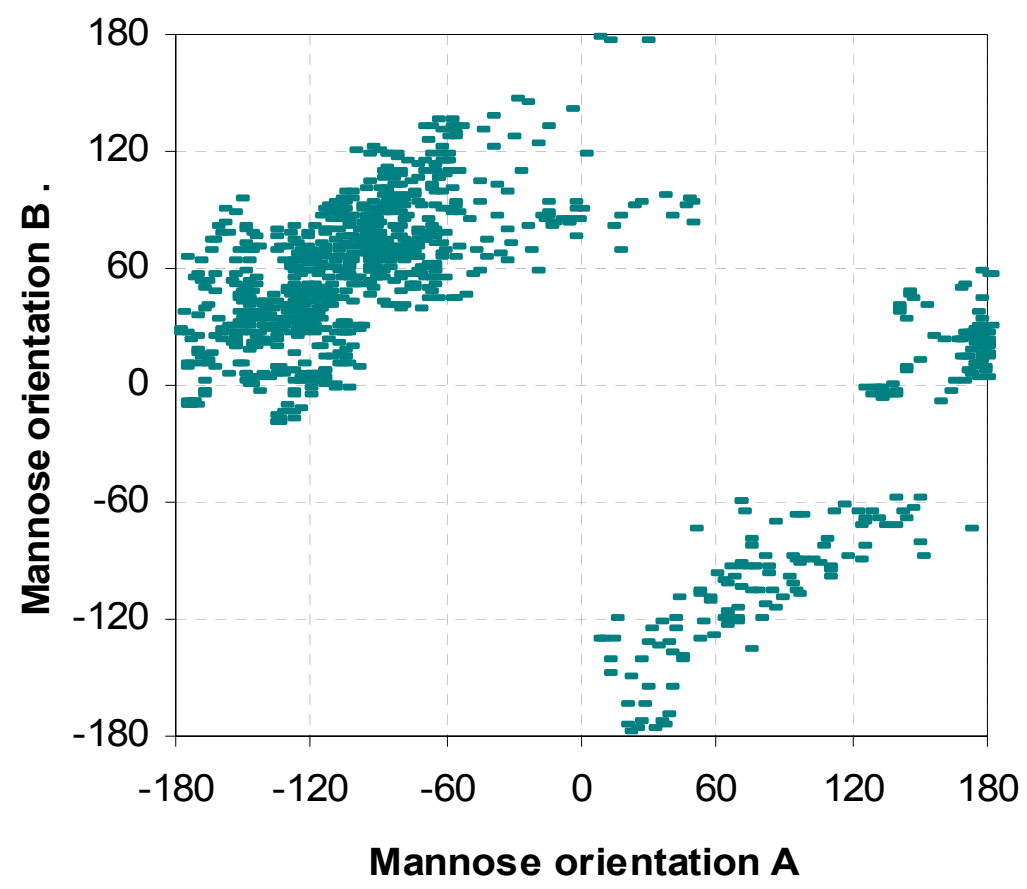




\section{Compound 4}

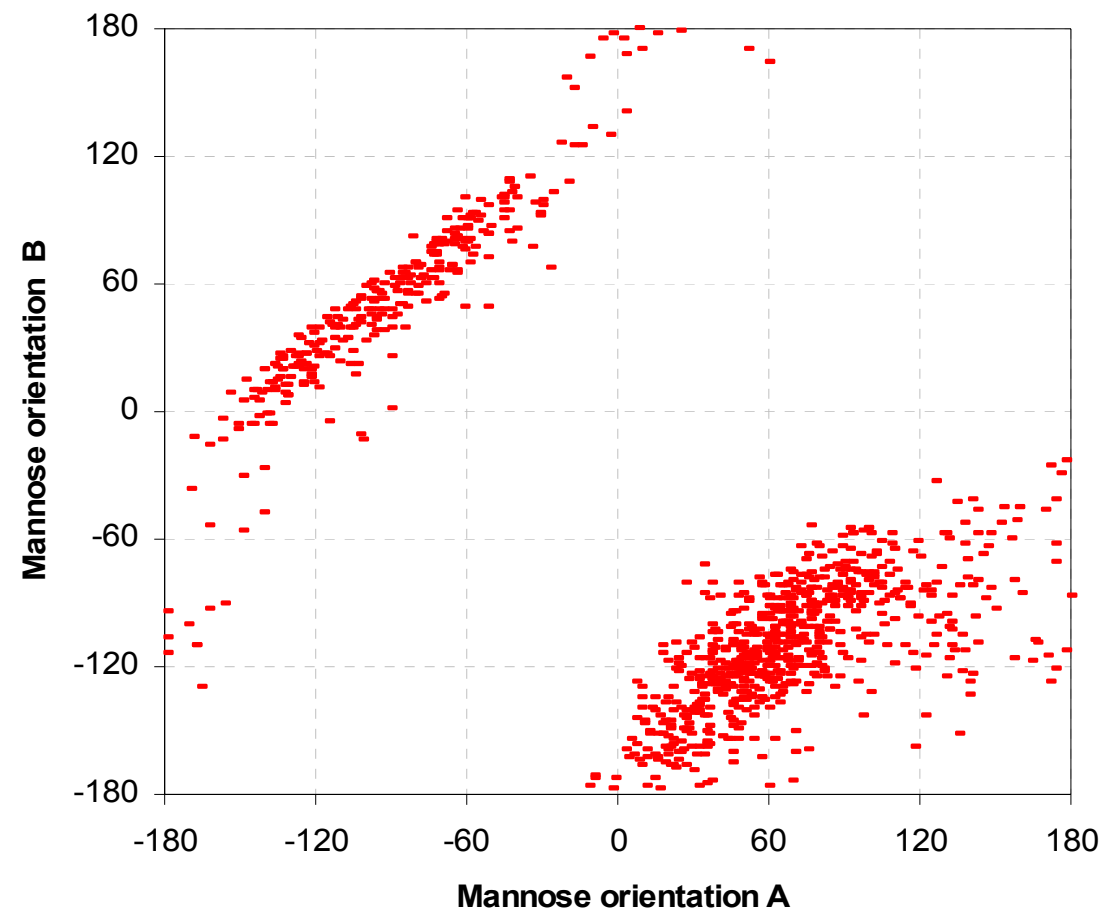

\section{Analysis of Mannose-Mannose distance}

\section{A. Man-Man distance for Compound 2}

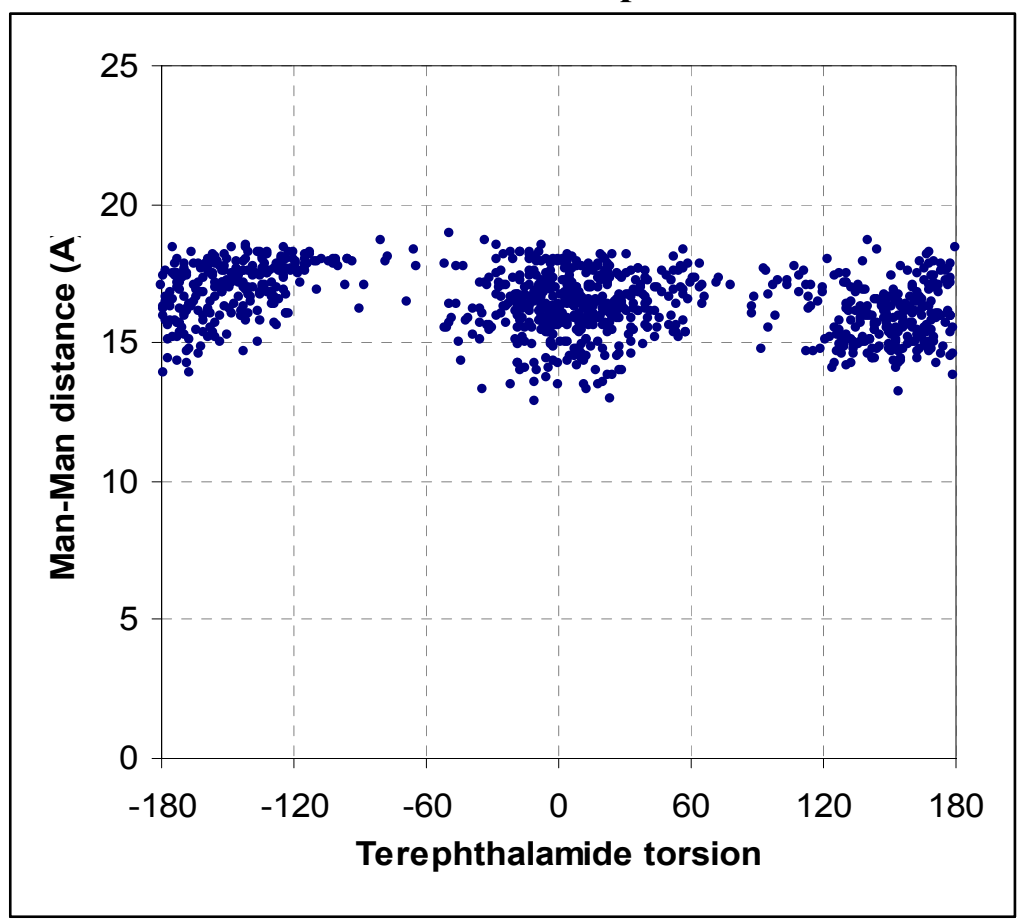


B. Mannose-Mannose distance for Compound 3

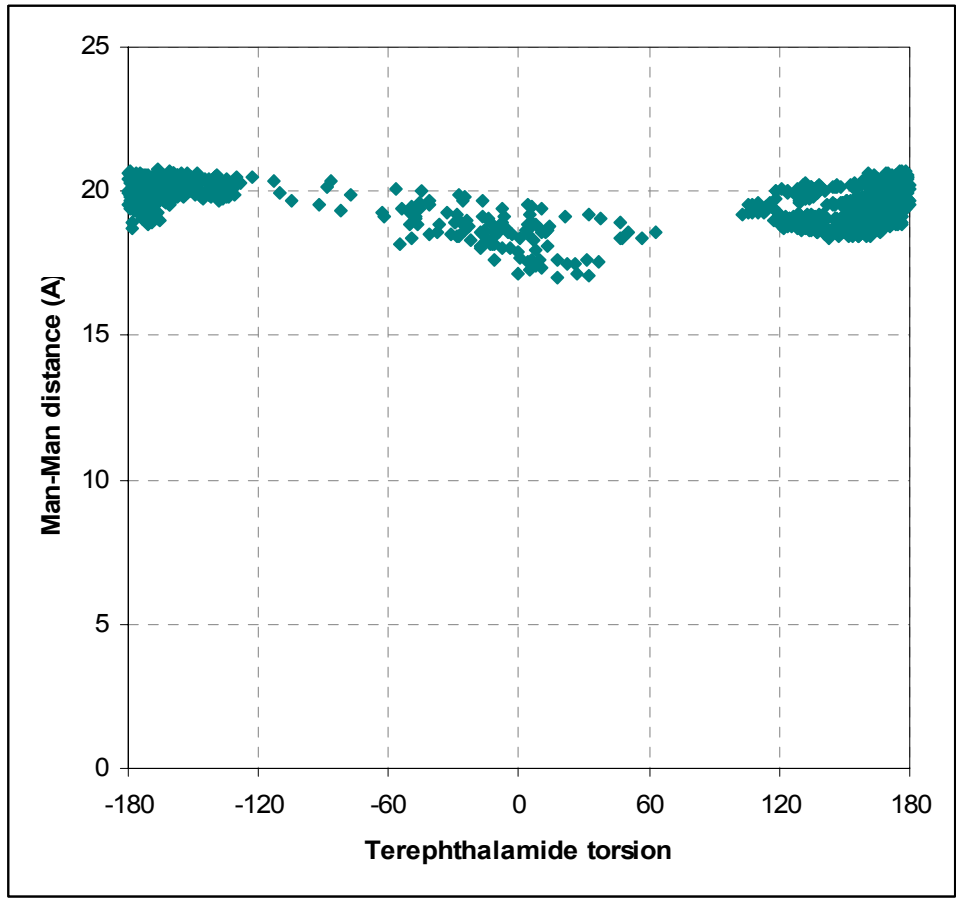

C. Man-Man distance for 4

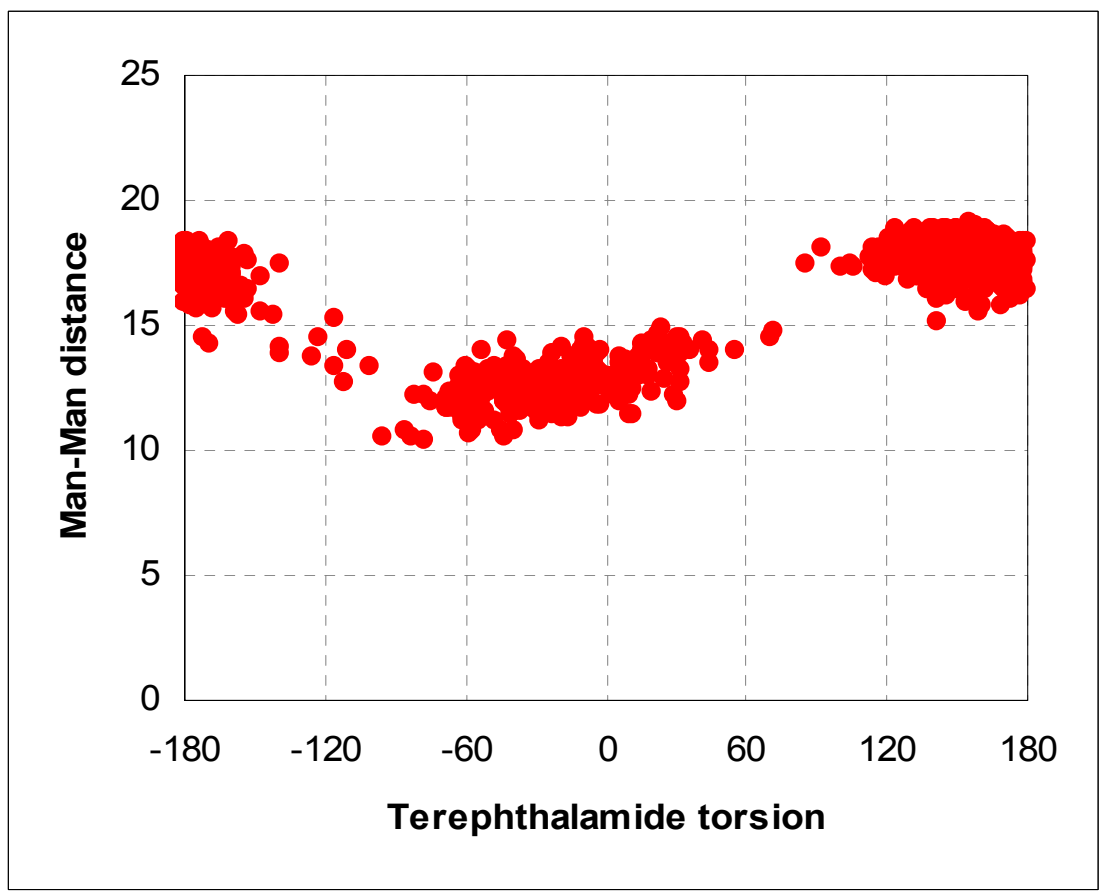


7. Average Glucose/GIcA H1-C1-N-H Angles (Standard Deviation) from simulations

$\begin{array}{llll}\text { Compound } & \mathbf{2} & 178.0^{\circ} & (4.7) \\ \text { Compound } & \mathbf{3} & 175.5^{\circ} & (3.2) \\ \text { Compound } & \mathbf{4} & 173.7^{\circ} & (4.6)\end{array}$

